\title{
Biological and Biochemical Basis of the Differential Efficacy of First and Second Generation Somatostatin Receptor Ligands in Neuroendocrine Neoplasms
}

\author{
Federico Gatto ${ }^{1,2,+}{ }^{\circ}$, Federica Barbieri ${ }^{1,+}+\mathbb{D}$, Marica Arvigo ${ }^{1,2}$, Stefano Thellung ${ }^{1}$, \\ Jessica Amarù 1,2, Manuela Albertelli ${ }^{1,2}$, Diego Ferone ${ }^{1,2}$ and Tullio Florio ${ }^{1,2, *(\mathbb{C})}$ \\ 1 Dipartimento di Medicina Interna \& Centro di Eccellenza per la Ricerca Biomedica (CEBR), \\ Università di Genova, 16132 Genova, Italy \\ 2 Istituto di Ricerca e Cura a Carattere Scientifico (IRCCS) Ospedale Policlinico San Martino, \\ 16132 Genova, Italy \\ * Correspondence: tullio.florio@unige.it; Tel.: +90-0103-5388-06 \\ $\dagger$ These authors contributed equally to this work.
}

Received: 1 January 1970; Accepted: 8 August 2019; Published: 13 August 2019

\begin{abstract}
Endogenous somatostatin shows anti-secretory effects in both physiological and pathological settings, as well as inhibitory activity on cell growth. Since somatostatin is not suitable for clinical practice, researchers developed synthetic somatostatin receptor ligands (SRLs) to overcome this limitation. Currently, SRLs represent pivotal tools in the treatment algorithm of neuroendocrine tumors (NETs). Octreotide and lanreotide are the first-generation SRLs developed and show a preferential binding affinity to somatostatin receptor (SST) subtype 2, while pasireotide, which is a second-generation SRL, has high affinity for multiple $\mathrm{SSTs}\left(\mathrm{SST}_{5}>\mathrm{SST}_{2}>\mathrm{SST}_{3}>\mathrm{SST}_{1}\right)$. A number of studies demonstrated that first-generation and second-generation SRLs show distinct functional properties, besides the mere receptor affinity. Therefore, the aim of the present review is to critically review the current evidence on the biological effects of SRLs in pituitary adenomas and neuroendocrine tumors, by mainly focusing on the differences between first-generation and second-generation ligands.
\end{abstract}

Keywords: somatostatin receptors; somatostatin receptor ligands; pituitary adenomas; neuroendocrine tumors

\section{Introduction}

Somatostatin (somatotropin release-inhibiting factor, SRIF) is an endogenous, and ubiquitous hormonal peptide [1] acting though a family of five G-protein-coupled receptors, named somatostatin receptors (SST) 1 to 5, and represents one of the main physiological inhibitors of endocrine and exocrine hormone secretion [2]. SRIF rapidly showed a widespread physiological activity related to the diffuse expression of its receptors throughout the body [3,4]. In particular, SRIF is able to modulate immune responses [5,6] and gastro-enteric-pancreatic cell activity [7]. It also shows neurotransmission and neuromodulatory functions. Particularly, SRIF is mainly involved in learning and memory processes [8-10], related to $\beta$-amyloid clearing [11,12], and in chronic pain modulation [13]. However, while SRIF itself exhibits effects on neurotransmission, evidence for endogenous SRIF release from SRIF-containing interneurons is lacking [14]. In the central nervous system (CNS), the characterization of SST signaling is also complicated by the identification of a novel peptide, cortistatin, able to activate all the five SSTs [15]. Subsequently, SRIF was recognized to reduce cell proliferation, increase apoptosis, and inhibit angiogenesis in most tumor tissues [2-4,16]. Thus, the interest in the potential use of SRIF as an anti-proliferative agent grew in recent years. This novel potential pharmacological use, despite being preclinically tested with unique results in several human solid tumors, including breast and lung 
carcinomas and gliomas [3,4], acquired particular interest for neuroendocrine tumors, including both pituitary adenomas and gastro-entero-pancreatic (GEP), as well as thoracic neuroendocrine neoplasms (NENs). However, SRIF is not a useful tool in clinical practice due to both its short circulating half-life ( $<3 \mathrm{~min}$ in human serum), resulting in the need for continuous parenteral administration, and to the post-infusion rebound observed for a number of target hormones, such as growth hormone (GH) and insulin $[17,18]$.

Therefore, synthetic somatostatin receptor ligands (SRLs) have been designed based on the primary SRIF structure, in order to overcome the above-mentioned drawbacks. To date, three SRLs have been already approved in clinical practice due to anti-secretory activity in hormone-secreting pituitary adenomas and NENs [19-22]. In particular, the SRIF analogues octreotide (OCT) and lanreotide (LAN) have been approved by the US Food and Drug Administration (FDA) and the European Medicines Agency (EMA) for treating patients with advanced GEP NENs, after two phase 3 clinical trials $[23,24]$ showed a significant increase in the progression-free survival (PFS) of treated patients. On the other hand, pasireotide (PAS), which is a second generation SRL approved for treatment of GH-secreting and adrenonocorticotropic hormone (ACTH)-secreting pituitary adenomas, is still under evaluation for NENs.

NEN patients demonstrated a significant benefit from the use of OCT and LAN, which resulted in a prolonged disease control associated with a satisfactory safety profile.

However, the wide range of cell types expressing SSTs, including tumors of non-endocrine origin, and the observation that SRLs display anti-proliferative activity in preclinical models of these tumors [3,25-28], open the possibility of a wider anti-tumor use for these compounds including in patients suffering from non-endocrine neoplasia. However, no successful trials have been reported with the use of SRLs as anti-proliferative agents in non-endocrine tumors' patients so far.

Notwithstanding the negative results reported for non-endocrine tumors, several studies thoroughly characterized the expression pattern of the five SST subtypes in human tumors and the molecular intracellular mechanisms by which each of these receptors activates anti-secretory and anti-proliferative signals in tumor cells.

\subsection{Somatostatin Receptor Signaling}

Soon after the molecular cloning of a family of five SSTs with a specific, although sometimes overlapping, expression pattern, most studies focused on the identification of specific intracellular signaling modulated by each receptor subtype. However, after more than 20 years from the first receptor cloning, as far as most of the second messenger systems is concerned, most SST subtypes seem to activate a similar signaling cascade (Figure 1 depicts the better characterized intracellular pathways modulated by SSTs). In particular, all members of this receptor family are G-protein coupled receptors (GPCRs) acting through inhibitory $\mathrm{G}$ proteins $(\mathrm{Gi} / \mathrm{Go})$ [29]. Belonging to the inhibitory receptors, SSTs are able to inhibit cAMP production and PKA activation [30-32], which is associated with reduced activity of voltage-dependent $\mathrm{Ca}^{++}$channels. The latter activity was reported in different cell systems to be direct, mediated by the $\alpha$ subunit of Gi/Go [33], or induced indirectly either by the reduced PKA activity or by the $\beta \gamma$ subunit-dependent activation of inward-rectifier $\mathrm{K}^{+}$channels [4,34]. The net result of these combinations of intracellular signals is plasma membrane hyperpolarization, which leads to all the anti-secretory activity of SRIF, not only in endocrine cells but also in neurons [35]. This contributes to the cognitive effects of this peptide in the CNS [8]. The same mechanisms are currently considered the determinants of the anti-secretory activity of SRLs in hormone-secreting tumor cells, including pituitary adenomas and NENs.

On the other hand, several intracellular pathways common to most SST subtypes were identified with regard to their anti-proliferative effects. In particular, the activation of these receptors mainly exerts cytostatic effects due to the up-regulation of cyclin-dependent kinase (CDK) inhibitors (either p21 $1^{\text {cip1/Waf1 }}$ or p27kip2, according to the cell types analyzed) [36-39] or the zinc finger protein (Zac1) [40]. Of note, the observed up-regulation of both CDK inhibitors and Zac1 depend on the modulation of 
MAP kinase activity, which is one of the main pathways controlled by tyrosine kinase receptors to induce cell proliferation $[39,41-45]$.

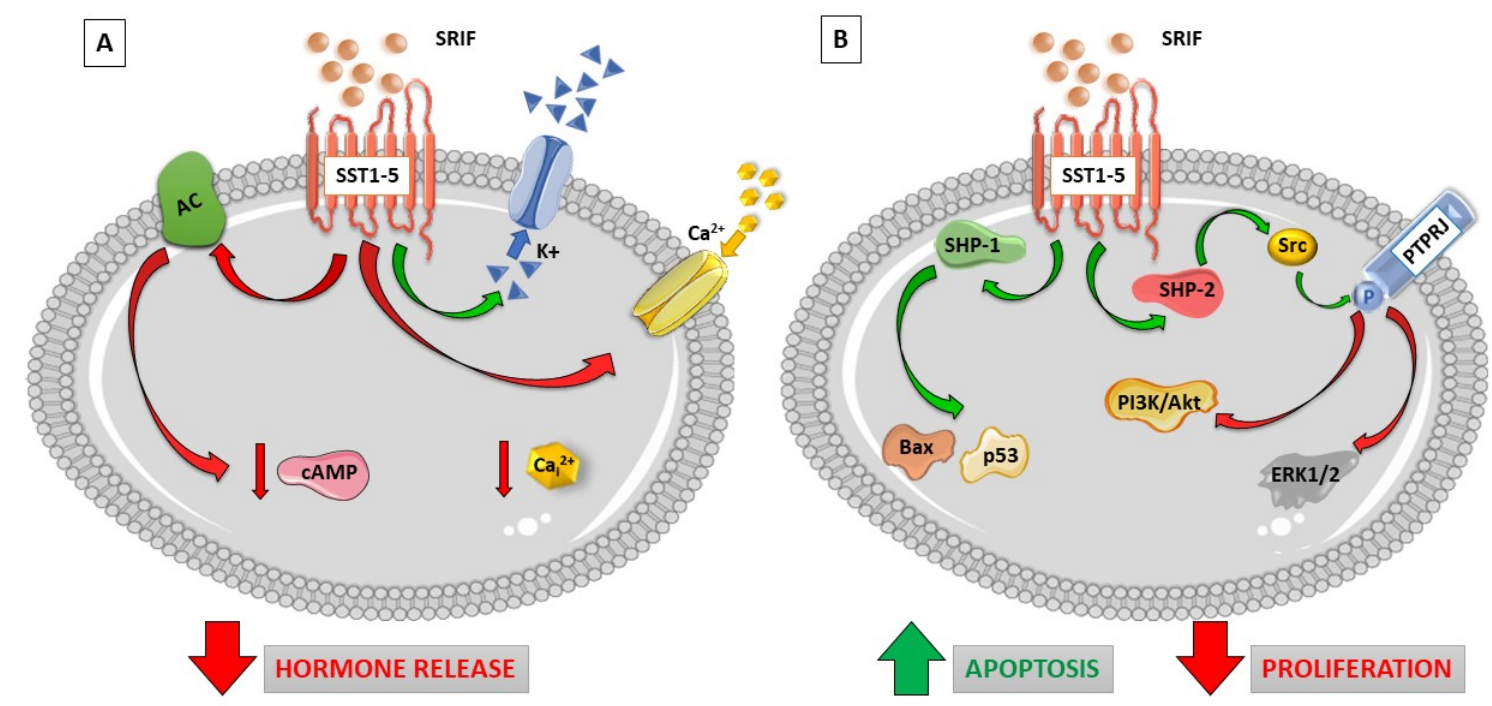

Figure 1. Diagram of the main intracellular signaling pathways triggered by agonist binding to somatostatin (SRIF) receptors to exert anti-secretory and anti-proliferative effects. (A) Anti-secretory activity of SRIF is regulated by: i) the inhibition of adenylyl cyclase (AC), lowering cyclic adenosine monophosphate (cAMP) levels; ii) the inhibition of voltage-dependent $\mathrm{Ca}^{2+}$ channels; and iii) the activation of outward $\mathrm{K}^{+}$channels, leading to cell membrane hyperpolarization. (B) Anti-proliferative effects of SRIF are mediated by the activation of the protein tyrosine phosphatases Src homology 2 domain-containing protein tyrosine phosphatase 1 and 2 (SHP-1 and SHP-2) and the protein tyrosine phosphatase receptor type J (PTPRJ). SHP-1 triggers intracellular pro-apoptotic signals involving the induction of p53 and Bax, while SHP-2 activates the tyrosine kinase Src that induces the phosphorylation of PTP $\eta$, which, in turn, dephosphorylates PI3K/Akt and ERK1/2, impairing cell proliferation. Green arrows: Activated pathway. Red arrows: Inhibited pathways.

However, distinct mechanisms were observed after SST activation in different cell systems, which causes either inhibition or activation of MAP kinases. In most studies, an inhibitory effect was observed. In fact, the activation of all five SSTs leads to protein tyrosine phosphatase (PTP) activation, as initially discovered by Pan \& Coll. [46], to inhibit tyrosine kinase-related mitogenic signaling pathways. Some PTPs were then associated with specific SST activity by biochemical assays, including the cytosolic Src homology region 2 domain-containing phosphatase 1 (SHP1) and 2 (SHP2), and the human receptor-like tyrosine phosphatase PTPRJ (or, as shown in most of the studies, its murine homologue PTP $)$ [47,48]. In primary cultures of GH-secreting and non-functioning pituitary adenomas, LAN induces anti-proliferative activity through the induction of a PTP activity $[49,50]$, while OCT triggers SHP1 activity in GH4C1 rat pituitary adenoma cell line [51]. SHP1 and/or SHP2 activities

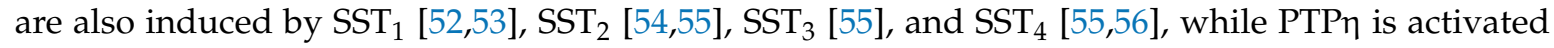
by $\mathrm{SST}_{1}, \mathrm{SST}_{2}$, and $\mathrm{SST}_{5}$, as shown in cells endogenously expressing the different SST subtypes [41]. The molecular mechanisms connecting SSTs and PTPs have not been completely clarified, but likely are not directly induced by $\mathrm{G}$ protein activation and involve the modulation of different intracellular transducers [47]. However, one of the main targets of the SRIF-induced PTP activity are the MAP kinases ERK1/2, whose dephosphorylation leads to an inhibition of growth factor activity and cell proliferation arrest $[41,42,44,57,58]$. Other studies reported that all SSTs can activate phospholipase C (PLC) [59], which promotes inositol-1,4,5-trisphosphate formation and $\mathrm{Ca}^{++}$release from intracellular stores, and activates protein kinase C (PKC). This signaling causes the activation of MAPK pathway [60], although $\mathrm{SST}_{1}$ and $\mathrm{SST}_{5}$-dependent anti-proliferative effects are observed in this situation due to the

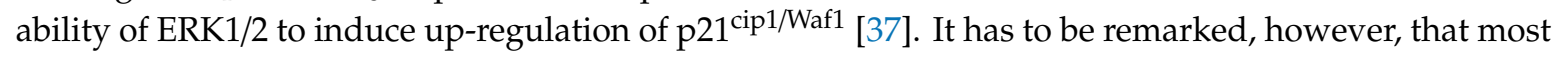


of the studies showing an SRIF-dependent activation of the PLC/ERK1/2 pathway were performed in heterologous SST-expressing cells. Therefore, the relevance of this evidence in human cells in vivo is still unclear.

Lastly, $\mathrm{SST}_{2}$ and $\mathrm{SST}_{4}$, but not $\mathrm{SST}_{3}$, were shown to increase the activity of p38, which is another MAP kinase family component mainly endowed with anti-proliferative and pro-apoptotic effects that causes the overexpression of $\mathrm{p} 21^{\text {cip1/Waf1 }}$ and growth arrest [61].

Heterologous SSTs expression was also reported to induce pro-apoptotic effects [62]. In particular, this was shown for $\mathrm{SST}_{3}$, which, when expressed in CHO-K1 cells, causes the activation of the apoptosis-related proteins p53 and Bax [63]. Similarly, besides cytostatic effects, $\mathrm{SST}_{2}$ induces the activation of pro-apoptotic signaling, through the inhibition of the anti-apoptotic factor Bcl-2 [64]. The signaling differences observed in different cell types, and, in particular, the different signaling observed after SSTs transfection, support the notion that, besides the specific biochemical features of receptors, the responses that can be obtained are also extremely dependent on the cell context where the receptors are activated.

Another relevant pathway, related to SRIF anti-tumor activity, is its ability to directly inhibit neoangiogenesis in different tumors [4], including those of a neuroendocrine origin [65].

This is mainly a direct effect on vessel formation, as demonstrated in in vivo studies [66], and involved the activity of $\mathrm{SST}_{1}$ [67], $\mathrm{SST}_{2}$ [68], and SST 3 [69]. The specificity of the SST-dependent anti-angiogenic effect, when compared to the direct anti-tumor activity was demonstrated, by the observation that it was, in most cases, independent of PTPs, but it involves the inhibition of cAMP accumulation [70] and, more importantly, the activity of endothelial nitric oxide synthase (eNOS) and the consequent generation of nitric oxide (NO) [69]. Importantly, the activation of all SSTs, except for $\mathrm{SST}_{4}$, was shown to be able to inhibit the eNOS-dependent or neural NOS-dependent NO production, independently of the mechanisms by which the enzyme was induced, which suggests a direct modulation of their activity [71,72]. Conversely, truncated isoforms of SST $_{5}$ (SST 5 TMD4), recently identified in different tumor histotypes as possible inhibitors of canonical SRIF activity on its receptors [73], were reported to stimulate the pro-angiogenic pathways. This results in an increased lymphatic metastasis in breast cancer [74].

Lastly, it was reported that $\mathrm{SST}_{1}, \mathrm{SST}_{3}$, and $\mathrm{SST}_{4}$ activation leads to the inhibition of the $\mathrm{Na}^{+} / \mathrm{H}^{+}$ exchanger (NHE1), causing intracellular acidification [75], which may be responsible for anti-migration activity observed by SST activation in several tumor cells [45]. In agreement with this observation, $\mathrm{SST}_{1}$ activation was also reported to inhibit Rho GTPase, involved in the cytoskeleton reorganization, cell adhesion, and cell motility, and regulated by NHE1 activity [76].

\subsection{Somatostatin Receptor Homo-Dimerization and Hetero-Dimerization}

Dimerization is a novel frontier in the regulation of the activity of GPCRs. In fact, this receptor family activity is modulated by homo-dimerization or hetero-dimerization, the latter possibly occurring between two GPCRs of the same or different families. While a variable degree of dimerization may occur according to the GPCR family involved, this process can represent either a constitutive event, occurring in the endoplasmic reticulum during receptor synthesis and representing a prerequisite for their correct membrane insertion, or, in other situations, dimerization can be induced by ligand binding [77]. It is currently accepted that heterodimerization results in the diversification of GPCR functioning, the modification of ligand binding affinity, intracellular signaling, receptor internalization, desensitization, and recycling [78].

After heterologous expression in both CHO-K1 and HEK-293T cells, $\mathrm{SST}_{2}$ and $\mathrm{SST}_{3}$ form constitutive homodimers, which progressively dissociate in the presence of increasing concentrations of SRIF, independently form the receptor concentration [79,80]. Conversely, in the same cell lines, human $\mathrm{SST}_{5}$ does not form constitutive dimers, which are formed only after treatment with SRIF [81]. A different response was observed for $\mathrm{SST}_{1}$, which never forms homodimers [82].

More complex results were provided with regard to heterodimerization. Several pharmacological evaluations showed different responses to SST agonists according to the receptor repertoires in a given 
cell, which is possibly dependent on the interaction between different receptor subtypes, although not formally demonstrated. For example, in C6 glioma cells, natively expressing all SSTs but $\mathrm{SST}_{4}$, all endowed with anti-proliferative activity via the activation of PTP $\eta$ and the inhibition of ERK1/2, the concomitant activation of $\mathrm{SST}_{1}$ and $\mathrm{SST}_{2}$ caused a synergistic cytostatic effect representing a possible heterodimerization effect. This did not occur with $\mathrm{SST}_{2}$ and $\mathrm{SST}_{5}$, whose combined activation resulted in a response resembling the $\mathrm{SST}_{5}$ individual effects [41].

More direct evaluations were also performed after cell transfection with individual receptors. It was observed that complexes formed among SST subtypes are formed following specific structural determinants, rather than occurring in the presence of random combinations. Thus, it was proposed that these events are highly selective and not all the receptor dimer combinations are possible. The first heterodimers observed are the complexes between $\mathrm{SST}_{2}$ and $\mathrm{SST}_{3}$ [80], and $\mathrm{SST}_{1}$ and $\mathrm{SST}_{5}$ [83]. Immunoprecipitation studies in prostate carcinoma cell lines showed that $\mathrm{SST}_{1} / \mathrm{SST}_{2}$ and $\mathrm{SST}_{2} / \mathrm{SST}_{5}$ heterodimers can be generated by natively expressed molecules. In these cells, receptor complexes are constitutively present within plasma membrane and their formation rate is increased by bispecific agonist binding (BIM-23704 and BIM-2324, respectively), which potentiates anti-proliferative responses [84]. In some cases, SST heterodimerization subverts receptor functioning, since $\mathrm{SST}_{2} / \mathrm{SST}_{3}$ heterodimer formation causes loss of $\mathrm{SST}_{3}$ activity while $\mathrm{SST}_{2}$ function is not changed [80]. On the other hand, $\mathrm{SST}_{1} / \mathrm{SST}_{5}$ dimers show higher affinity for SRIF as compared to individual receptors [83]. $\mathrm{SST}_{3}$ within dimers loses its internalization ability, conferring to $\mathrm{SST}_{2} / \mathrm{SST}_{3}$ heterodimers that increased resistance to agonist-dependent desensitization [80]. More recently, co-immunoprecipitation studies performed in MDA-MB- $435 \mathrm{~S}$ breast cancer cells, reported the formation of $\mathrm{SST}_{1} / \mathrm{SST}_{4}$ heterodimers in basal condition, which was increased after treatment with SRLs. This resulted in a potentiation of the anti-proliferative activity [85].

$\mathrm{SST}_{2} / \mathrm{SST}_{5}$ heterodimers are particularly relevant since these receptors are the target of the clinically approved SRLs. In co-transfected HEK-293 cells, selective activation of $\mathrm{SST}_{2}$, but not that of $\mathrm{SST}_{5}$ or the coactivation of both SST subtypes, was able to favor the association between these SST subtypes. However, $\mathrm{SST}_{2}$ activation caused a higher inhibition of cAMP and a more potent modulation of

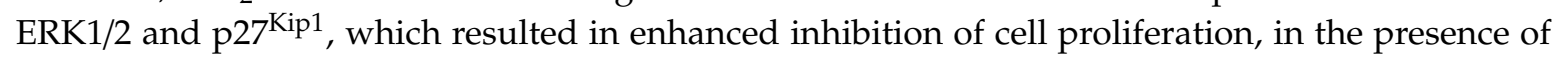
both receptors than in cells expressing SST $_{2}$ alone [86]. Moreover, upon agonist-dependent activation, monomeric $\mathrm{SST}_{2}$ rapidly desensitize due to $\beta$-arrestin binding. Heterodimers display destabilization of the $\beta$-arrestin-receptor interaction, which increases the rate of the membrane recycling of internalized receptors [86]. This mechanism was proposed as one of the molecular determinants for SRL effectiveness in controlling pituitary tumors and the absence of tolerance seen in patients undergoing long-term SRL administration.

SST functioning is also modified by dimer generation with components of other GPCR families, including opioid [87] and dopamine receptors [88,89]. In particular, $\mathrm{SST}_{2}$ is able to heterodimerize with the $\mu$ opioid receptor-1 (MOR1), after heterologous transfection in HEK-293 cells [87]. This event does not change the signaling properties of the receptors but causes the desensitization and endocytosis of both the components of the dimer in response to SRLs [87]. SST 5 and dopamine-2 receptor (D2R) interaction was demonstrated in co-transfected $\mathrm{CHO}-\mathrm{K} 1$ cells. In the absence of ligand stimulation, these receptors do not heterodimerize. However, in the presence of either SST-specific or D2R-specific ligands, a significant association between the two receptor subtypes was observed [88,89]. This heterodimer displays a completely different pharmacology as compared to individual receptors, with increased (or decreased) affinity to SRIF in the presence of D2R agonists (or antagonists) able to potentiate (or inhibit) the ability of SRLs to affect cAMP production [88]. More recently, heterodimerization between $\mathrm{SST}_{5}$ and $\beta 1$ adrenergic receptor ( $\beta 1-\mathrm{AR}$ ), was also shown in co-transfected HEK-293 cells. $\mathrm{SST}_{5} / \beta 1 \mathrm{AR}$ heterodimers, already detected in untreated conditions, were highly increased in the presence of agonists for both receptors. However, the individual binding of $\beta 1$-AR or $\mathrm{SST}_{5}$ caused dimer dissociation. After co-treatment, $\beta 1$-AR increase in cAMP production was the predominant effect, while ERK1/2 activity was predominantly regulated by $\mathrm{SST}_{5}$ [90]. 
Thus, heterodimerization among SSTs, or with other GPCRs, can represent a significant interfering factor to be taken into account when patients are treated with ligands able to bind more receptors, and it could explain the different tissue responses (including those of tumor origin) characterized by specific receptors repertoire. Since the clinically approved SRLs (OCT, LAN, and PAS, see next paragraph) display high affinity binding to multiple SSTs, and receptor repertoire of the target cells included the presence of apparently off-target receptors able to heterodimerize with SSTs, which could dramatically change the responses to these drugs. However, this issue has not yet been deeply analyzed and will require further investigation in the coming years.

\section{2. "Old" and "New" Somatostatin Receptor Ligands}

As mentioned in the previous paragraphs, anti-secretory and anti-proliferative effects of native SRIF are currently exploited using synthetic SRLs, among which OCT and LAN were the first drugs clinically approved $[18,91]$. They are both small molecules (octapeptides), which retain the Cys-Cys bridge present in native SRIF and then stabilizing the structure substituting a Tryptophan (Trp) with its D-enantiomer (D-Trp). Therefore, these compounds show enhanced half-life compared to SRIF (about $2 \mathrm{~h}$ for OCT and 90 minutes for LAN) as well as lower clearance, which results in longer duration of action and long-lasting biological activity $[18,92]$. Both compounds show a preferential binding affinity to $\mathrm{SST}_{2}$. As for the other SST subtypes, OCT has moderate affinity for $\mathrm{SST}_{5}$ and a weak interaction with $\mathrm{SST}_{3}$, while LAN shows a slightly more pronounced affinity to $\mathrm{SST}_{5}$. Of note, differently from native SRIF, both octapeptides have a negligible binding to $\mathrm{SST}_{1}$ and $\mathrm{SST}_{4}$ (Figure 2) [93,94].

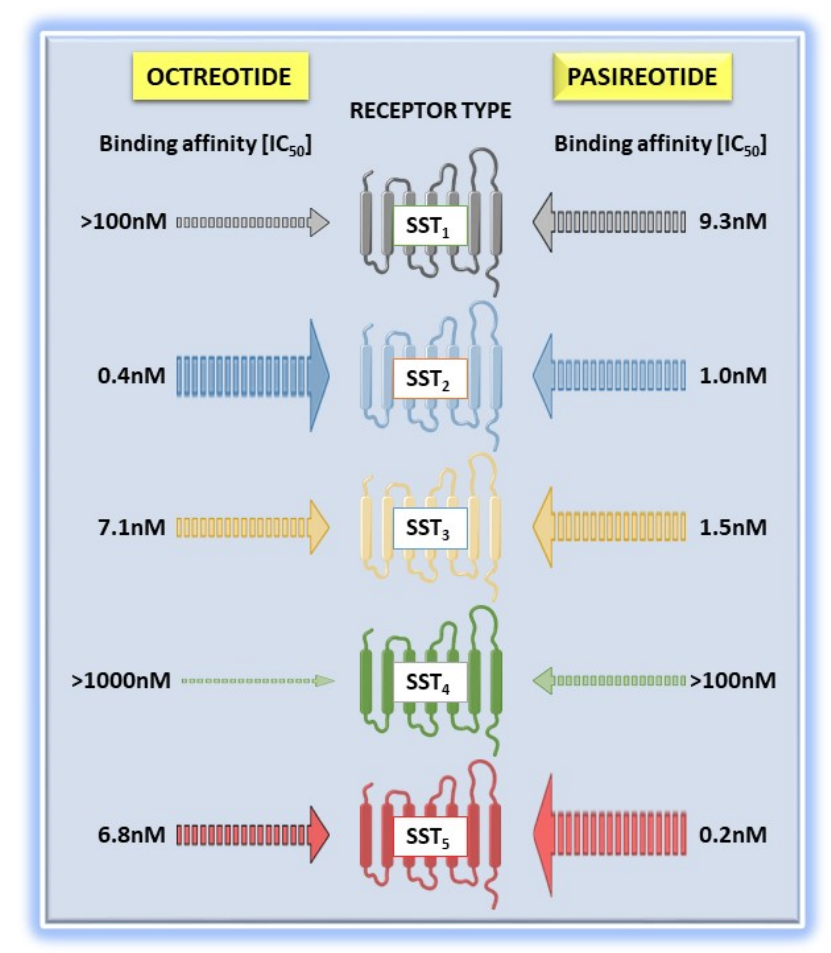

Figure 2. Octreotide and pasireotide binding affinity toward human somatostatin receptor subtypes.

OCT and LAN became clinically available in the last 30 years, with different formulation developed, tested, and then approved by both EMA and FDA [95]. First, in 1988, a short-acting formulation of OCT, administered subcutaneously (s.c.) or intravenously (i.v.), received approval for treating acromegaly patients in Europe, while the long-acting repeatable formulation (LAR, long-acting repeatable) was introduced and approved in 1995. The technology underlying OCT LAR formulation consists in a depot preparation in which OCT molecules are encapsulated in microspheres of a biodegradable polymer. The LAR formulation allows clinicians to treat patients with an intramuscular (i.m.) injection 
every four weeks, instead of the standard three s.c. administrations/day required for the short-acting drug. A single OCT LAR injection results in an initial peak within 1 hour of administration, with a progressive decrease in the following $12 \mathrm{~h}$, and a subsequent second-release phase showing a sustained drug release reaching a plateau between days 14-42 [96]. Of note, the steady-state concentrations of OCT in serum are reached after three LAR injections. Currently, OCT LAR is commercially available in three different dosages $(10,20$, and $30 \mathrm{mg}$ ), with a maximum allowed dose of $40 \mathrm{mg}$ (two $20 \mathrm{mg}$ injections in acromegaly) every four weeks.

As far as LAN is concerned, the first approved formulation consisted in a sustained-release formulation (LAN SR), developed using a microparticle-based delivery system. LAN SR is available as a power for suspension for intramuscular injection at a dosage of $30 \mathrm{mg}$. Starting treatment schedule is recommended as $30 \mathrm{mg} / 14$ days, but subsequent injections may be given every seven to 10 days, depending on patients' responses. However, in 2001, another LAN formulation, LAN Autogel, has been approved by EMA for treating acromegaly patients [95]. LAN Autogel represents the first available sustained-release formulation based on self-assembling nanotube technology [97], available in prefilled syringes (dosages 60-90-120 mg) administrated by deep s.c. injection every four weeks, even though administration frequency can be modulated according to the patient's response (i.e., every three to five weeks) [98]. Therefore, the improved patients' compliance, determined that, currently, LAN Autogel has almost completely replaced the SR formulation in daily clinical practice. LAN Autogel has a different release pattern than OCT LAR, since peptide monomers are slowly released by the nanotubes after injection. In more detail, the drug pharmacokinetic is characterized by an initial acute increase of serum LAN concentrations, which reaches a peak during day 1 , followed by a gradual decrease during the following four weeks [99].

Lastly, PAS represents a second-generation SRL. The molecule consists of a stable cyclohexapeptide with a long half-life (about $24 \mathrm{~h}$ ), synthetized based on the SRIF structure and showing high affinity for multiple SSTs $\left(\mathrm{SST}_{5}>\mathrm{SST}_{2}>\mathrm{SST}_{3}>\mathrm{SST}_{1}\right)$. In detail, different from the first-generation SRLs, $\mathrm{OCT}$, and LAN, PAS shows a binding affinity in the low nanomolar range for $\mathrm{SST}_{5}\left(\mathrm{IC}_{50}: 0.2 \mathrm{nM}\right), \mathrm{SST}_{2}\left(\mathrm{IC}_{50}\right.$ : $1 \mathrm{nM}$ ), and $\mathrm{SST}_{3}\left(\mathrm{IC}_{50}: 1.5 \mathrm{nM}\right.$ ) (Figure 2) [100].

Since first-generation SRLs mainly target $\mathrm{SST}_{2}$, but different SST subtypes are heterogeneously expressed in pituitary and neuroendocrine tumors, researchers aimed to generate a compound with a more universal binding profile for SSTs, similar to that of native SRIF. Among a number of novel compounds tested in vitro and described in the recent literature [28,101], PAS is the only SST pan-ligand that has been approved by EMA and FDA for clinical use.

Currently, two formulations of PAS are available for clinical practice: a short-acting s.c. formulation approved for treating Cushing's disease, and a long-acting formulation (PAS LAR) for intramuscular injection developed using the same technology than OCT LAR, which was approved for treating Cushing's disease and acromegaly [95].

Short-acting PAS is available as a solution for s.c. injection in three dosages $(0.3 \mathrm{mg}, 0.6 \mathrm{mg}$, and $0.9 \mathrm{mg}$ ), with a recommended starting treatment schedule of $0.6 \mathrm{mg}$ twice a day. On the other hand, PAS LAR is available as powder and solvent for deep intramuscular injection at different dosages (20 mg, $40 \mathrm{mg}$, and $60 \mathrm{mg}$ ), with a recommended starting dose of $40 \mathrm{mg} /$ four weeks and a maximum allowed dose of $60 \mathrm{mg} /$ four weeks. Studies in healthy volunteers show that PAS s.c. is rapidly absorbed, with maximum plasma concentrations reaching in $<1 \mathrm{~h}$ [102], while, similarly to that observed for OCT LAR, PAS LAR exhibits an extended-release profile with an initial burst release, a subsequent decline of plasma concentrations, and then another increase rising to a peak over approximately one week and three weeks [103].

To summarize, PAS shows a pattern of binding affinity for SSTs similar to native SRIF compared to first-generation analogs. However, despite the initial search for a compound able to closely mimic native SRIF effects, and possibly overcoming its limitations (i.e., short half-life), a number of studies already demonstrated that PAS has different functional properties compared to both SRIF and first-generation SRLs when binding SSTs, and particularly $\mathrm{SST}_{2}$. These differences, going beyond the different binding properties for membrane receptors, will be described in detail in the following chapter of the review. 


\section{Differential Functional Properties of Somatostatin Receptor Ligands}

First-generation and second-generation SRLs differ in their biological properties, which causes different biological responses, including SST pathway activation and modulation of receptors' phosphorylation, internalization, and trafficking.

As mentioned above, the first clear difference resides in a broader SST binding affinity of PAS compared to both OCT and LAN [100]. Particularly, the significantly higher binding affinity of PAS for $\mathrm{SST}_{5}$ results in a more potent activation of different intracellular pathways. In more detail, Lesche \& Coll. demonstrated that, in HEK 293 cells stably transfected with human SST 5 , PAS was superior to OCT in decreasing intracellular cAMP levels and in the stimulation of ERK1/2 phosphorylation [104]. This evidence, derived from transfected cell models, is in line with subsequent preclinical studies carried out in corticotroph pituitary cells (mainly expressing SST $_{5}$ among all SST subtypes), which show a greater efficacy of PAS, compared to first-generation SRLs, in the inhibition of basal and/or CRH-stimulated ACTH secretion [105,106].

However, the differences between first-generation and second-generation SRLs go far beyond the mere membrane receptor binding. The specific intracellular pathways activated by SRLs, as well as their potency, is different in the different tumor types, depending on the specific SST distribution pattern, as well as signaling elements, receptor desensitization, internalization, and cross talk $[107,108]$.

Since $\mathrm{SST}_{2}$ is the SST subtype mostly expressed in the majority of pituitary adenomas and NENs, and first-generation SRLs mainly target $\mathrm{SST}_{2}$, most studies focused on the differential activation of this specific SST subtype when investigating the biological differences between PAS and the other SRLs.

In this context, a number of studies demonstrated that, in the same cell type, PAS may elicit differential effects compared to both OCT, native SRIF, and SST selective ligands, when targeting $\mathrm{SST}_{2}$, possibly due to the activation of different subsets of intracellular mediators [104,108-110].

This phenomenon, also named biased-agonism, depends on specific agonist-receptor interactions. In this light, Cescato \& Coll. observed that, in HEK 293 cells stably transfected with rat $\mathrm{SST}_{2}$ and rat pancreatic AR42J cells, PAS is less potent than OCT in inhibiting intracellular cAMP production. Furthermore, differently from OCT, it antagonizes SRIF modulation of intracellular $\mathrm{Ca}^{++}$concentrations $\left(\left[\mathrm{Ca}^{++}\right] \mathrm{i}\right)$, and behaves as partial agonists for SRIF-mediated ERK1/2 phosphorylation [111]. These data were in line with previous findings showing that, in HEK cells transfected with human $\mathrm{SST}_{2}$, PAS induced a less potent cAMP synthesis inhibition and a lower ERK1/2 phosphorylation compared to both OCT and native SRIF [104].

Despite SRIF, OCT, and PAS show similar binding affinity for $\mathrm{SST}_{2}$ (within the low nanomolar range), PAS was reported to induce an $\mathrm{SST}_{2}$ phosphorylation pattern and trafficking rate, that were clearly different to those caused by OCT and native SRIF [104,109,110,112]. In this context, similarly to several other GPCRs, $\mathrm{SST}_{2}$ undergoes agonist-induced endocytosis following agonist binding. The activated receptor is then phosphorylated by $G$ protein coupled receptor kinases (GRKs) and, subsequently, recruited by cytoplasmic proteins, named $\beta$-arrestins, which determines uncoupling between the receptor and its related $G$ proteins $[113,114]$. The receptor $/ \beta$-arrestin complex is then internalized by dynamin-dependent endocytosis. In more detail, regulation of $\mathrm{SST}_{2}$ involves the phosphorylation of specific serine (Ser) and threonine (Thr) residues identified in the C-terminal tail of the receptor. After SRIF and/or OCT stimulation, phosphorylation of Ser341, Ser343, Ser348, Thr353, and Thr354 has been observed in rat $\mathrm{SST}_{2}$-transfected $\mathrm{CHO}$ and $\mathrm{GH}_{4} \mathrm{C}_{1}$ cells [115], while Ser341, Ser343, Thr353, Thr354, Thr356, and Thr359 have been identified in HEK293 cells transfected with rat or human $\mathrm{SST}_{2}[112,116]$. Furthermore, an agonist-dependent $\mathrm{SST}_{2}$ phosphorylation of the four Thr residues has been documented in rat pituitary $\mathrm{GH}_{3}$ cells transfected with rat SST2, rat insulinoma $\beta$-cells (INS1 cells), and rat pancreas in vivo [110]. Of note, unlike SRIF and OCT, PAS stimulates only phosphorylation of Ser341 and Ser343 residues of human SST2, which is followed by a partial receptor internalization $[104,116]$. In this context, GRK2 and GRK3 have been pointed out as the receptor kinases mainly involved in $\mathrm{SST}_{2}$ phosphorylation of C-tail Ser and Thr residues, since GRK2/GRK3 upregulation results in an increased receptor phosphorylation both after OCT and PAS treatment [110,112]. 
The differential $\mathrm{SST}_{2}$ phosphorylation induced by PAS, as compared to SRIF and/or OCT, results in a striking different $\beta$-arrestin recruitment and receptor internalization rate. PAS causes a significantly lower internalization of $\mathrm{SST}_{2}$ compared to both OCT and SRIF in HEK cells transfected with the human receptor, as well as in rat cell lines and endocrine tissues (rat pituitary and pancreas) $[104,110,116]$. Another study confirmed that, compared to SRIF and/or OCT, the degree of $\mathrm{SST}_{2}$ internalization following PAS application is smaller, both in terms of potency and percent maximal internalization reached after receptor activation [109] (Table 1). These data on cell lines (SST 2 -transfected or endogenously expressing the receptor) have been recently confirmed in an elegant study carried out on human pancreatic neuroendocrine tumor primary cultures [117]. The authors observed that, differently from OCT, PAS results in a rapid and transient internalization of $\mathrm{SST}_{2}$ followed by a persistent recycling of the receptor at the cell surface. Based on our knowledge, there are no studies published so far evaluating the role of PAS compared to OCT and/or native SRIF on $\mathrm{SST}_{2}$ internalization and trafficking in primary cultures of somatotroph and/or corticotroph adenomas. This could be important to further confirm the above reported findings in a reliable model of human pituitary adenomas.

Table 1. Trafficking properties of transfected human and rat somatostatin receptor subtype $2\left(\mathrm{SST}_{2}\right)$ after binding to endogenous somatostatin (SRIF), octreotide (OCT), and pasireotide (PAS).

\begin{tabular}{|c|c|c|c|c|}
\hline $\begin{array}{c}\mathrm{SST}_{2} \\
\text { Trafficking Properties }\end{array}$ & Ligand & $\begin{array}{l}\text { Receptor Internalization } \\
\left(\mathrm{EC}_{50}, \mathrm{nM}\right)\end{array}$ & $\begin{array}{c}\text { Maximal Internalization } \\
(\% \text { of total })^{a}\end{array}$ & $\begin{array}{l}\text { Receptor Recycling } \\
\text { (min) } b\end{array}$ \\
\hline \multirow[t]{3}{*}{$\mathrm{hSST}_{2} *$} & SRIF & 3.26 & - & n.a. \\
\hline & OCT & 6.46 & - & n.a. \\
\hline & PAS & 31.78 & - & n.a. \\
\hline \multirow[t]{3}{*}{$\mathrm{rSST}_{2} * *$} & SRIF & 0.4 & 82.8 & 42.3 \\
\hline & OCT & n.a. & n.a. & n.a. \\
\hline & PAS & 23.3 & 46.0 & 4.8 \\
\hline
\end{tabular}

$\mathrm{hSST}_{2}$, human $\mathrm{SST}_{2} . \mathrm{rSST}_{2}$, rat $\mathrm{SST}_{2} . \mathrm{EC}_{50}$, half-maximal effective concentration. min, minutes. n.a. not assessed. In most preclinical studies, pasireotide (PAS) was named as SOM230.* Data about $\mathrm{hSST}_{2}$ are reproduced from Reference [102]. ${ }^{* *}$ Data about $\mathrm{rSST}_{2}$ refers to Reference [107]. ${ }^{\text {a }}$ Internalization of hSST2 is evaluated after $30 \mathrm{~min}$ of SRIF, OCT, and PAS treatment at $1 \mu \mathrm{M}$ concentration, while internalization of rSST2 is assessed after 90 min of SRIF $100 \mathrm{nM}$ and PAS $1 \mu \mathrm{M}$ concentration. ${ }^{\mathrm{b}}$ rSST2 recycling was measured after $30 \mathrm{~min}$ of SRIF $100 \mathrm{nM}$ and PAS $1 \mu \mathrm{M}$ concentration.

However, in line with analysis of current data investigating the agonist-dependent receptor internalization, multiple studies demonstrated that, after PAS binding, less $\beta$-arrestins are recruited to the cell membrane compared to SRIF treatment, which results in a less stable complex with $\mathrm{SST}_{2}[109,110]$.

Since $\beta$-arrestins play a pivotal role in the desensitization-internalization processes of GPCRs, including $\mathrm{SST}_{2}$, the agonist-dependent recruitment of these molecules may impact receptor signaling and drug efficacy. Our group recently demonstrated that $\beta$-arrestin expression correlates with the anti-secretory efficacy of first-generation SRLs in GH-secreting adenoma, both in vitro and in vivo $[118,119]$. In this light, the differential properties of PAS compared to both SRIF and first-generation SRLs shed light on the importance of the agonist-induced receptor conformation in affecting receptor signaling and regulation, besides and beyond agonist-binding affinity alone.

\section{Comparison between First-Generation and Second-Generation Somatostatin Receptor Ligands in Clinical Studies and Preclinical Models of Pituitary Tumors}

\subsection{Acromegaly}

Acromegaly is a severe systemic condition mainly dependent on somatotroph pituitary adenomas. It is characterized by high plasma levels of GH and IGF-1 leading to increased mortality and morbidity [120]. Treatment of acromegaly aims to normalize GH and IGF-1 levels, which reestablishes a normal life expectancy [120]. The first line treatment in most acromegaly patients is represented by trans-sphenoid surgery since it provides instantaneous reduction of GH levels with low complication 
rates [121]. However, up to $50 \%$ of patients with macroadenomas do not normalize GH and/or IGF-1 levels, which, therefore, require medical adjuvant therapy [122,123].

To date, first-generation SRLs, OCT, and LAN represent the first line medical treatment of acromegaly because of the predominant expression of $\mathrm{SST}_{2}$ on tumor pituitary cells [124]. However, studies on long-term efficacy and safety of first generation SRLs demonstrated that only $30 \%$ to $40 \%$ of patients achieve normalization of predefined GH and IGF-1 levels during long-term treatment [125], even though a significant percentage of pituitary adenomas shows a variable degree of shrinkage during long-term SRL treatment. Moreover, only a small subgroup of GH-secreting adenomas is truly SRL resistant, mainly because $\mathrm{SST}_{2}$ expression is lacking or extremely low. In this context, the second-generation SRL PAS, displaying increased affinity for SSTR ${ }_{5}$ and other SSTRs, may have adjunctive effect over OCT or LAN.

The first in vitro study comparing the effect of OCT and PAS on GH secretion was performed on GHRH stimulated primary cultures of rat anterior pituitary cells after $3 \mathrm{~h}$ of treatment with the compounds [100]. This study showed that PAS-dependent GH reduction was three-fold to four-fold higher compared to both SRIF and OCT, with a half-maximal inhibitory concentration $\left(\mathrm{IC}_{50}\right)$ in the sub-nanomolar range $(0.4 \pm 0.1 \mathrm{nM}$ PAS vs. $1.5 \pm 0.3 \mathrm{nM}$ SRIF, and $1.3 \pm 0.2 \mathrm{nM} \mathrm{OCT})$. Moreover, the same study compared the efficacy of OCT and PAS in the modulation of GH, IGF-1, insulin, and glucagon levels in rat animal models, after both short-term and long-term treatment (1 hour to 126 days). OCT demonstrated to be slightly more effective than PAS in reducing GH secretion after 1 hour of treatment (median effective dose [ED $\left.\mathrm{ED}_{50}\right] 0.13 \mathrm{vs} .0 .22 \mu \mathrm{g} / \mathrm{kg}$ ), whereas PAS was more effective than OCT after $6 \mathrm{~h}$ of treatment $\left(\mathrm{ED}_{50} 23.7 \mathrm{vs} .5 .5 \mu \mathrm{g} / \mathrm{kg}\right)$ demonstrating its prolonged biological action. After 126 days of continuous infusion at stable dose $(10 \mathrm{mg} / \mathrm{kg} / \mathrm{h})$, PAS also reduced IGF- 1 levels by $75 \%$ compared with placebo-treated animals, while OCT only caused a 30\% decrease of IGF-1 [100].

Different results were obtained in a subsequent in vitro study evaluating the effect of PAS, SRIF, and OCT on GH secretion in primary cultures from rat pituitary cells, human fetal pituitary tissues, and human GH-secreting pituitary adenomas [126]. After treatment of murine pituitary cells, no statistical difference between OCT and PAS were observed as far as the inhibition of $\mathrm{GH}$ secretion (IC $_{50}$ for PAS and OCT: 1.2 and $0.8 \mathrm{nM}$, respectively). Apparently, in line with the latter finding, results on human pituitary adenoma cell cultures $(n=6)$ demonstrated a superimposable effect of OCT and PAS in inhibiting GH secretion after $20 \mathrm{~h}$ of treatment. However, a careful analysis of individual human PA primary culture showed that PAS and SRIF inhibited GH secretion by more than $20 \%$ in five out of six samples, while OCT was as effective as PAS (or SRIF) only in three out of six tumors. The lack of statistical significance, as stated by authors, was likely due to the low number of samples analyzed [126]. In order to establish the prevalent SST subtype involved in PAS anti-secretory effect, the SST expression profile was evaluated in the six human pituitary cultures by reverse transcriptase (RT)-PCR. $\mathrm{SST}_{2}$ was expressed in all samples, while $\mathrm{SST}_{5}$ was expressed in only four out of six cultures. The effect of PAS in inhibiting GH secretion by more than $20 \%$, was observed in two $\mathrm{SST}_{5}$-negative samples suggesting, for the first time, that PAS could drive its effect through $\mathrm{SST}_{2}$ despite its higher binding affinity for $\mathrm{SST}_{5}$. However, the limited number of samples analyzed prevents the establishment of a conclusive correlation between SST differential expression and the anti-secretory effects of PAS, even though these results opened a new scenario because of their translational significance [126].

The role of $\mathrm{SST}_{2}$ as a mediator of a PAS anti-secretory effect on GH was confirmed in nine GH-secreting pituitary adenoma primary cultures, analyzing the effect of $10 \mathrm{nM} \mathrm{OCT}$, PAS, and SRIF on $\mathrm{GH}$ release after $72 \mathrm{~h}$ of treatment [127]. It was reported that the three compounds inhibit GH secretion in a superimposable manner in almost all tested cultures (SRIF 6/6, OCT 7/9, and PAS 8/9). Similar to the study by Murray \& Coll. [126], analysis of SST mRNA expression performed in seven of these tumor samples showed a predominant, although variable, expression of $\mathrm{SST}_{2}$ and $\mathrm{SST}_{5}$. However, apart from the previous study, a direct and significant correlation between $\mathrm{SST}_{2}$ mRNA expression and the anti-secretory activity of both OCT and PAS was demonstrated [127]. No correlation between the inhibitory effect of PAS on GH secretion and $\mathrm{SST}_{5}$ expression was found, despite the high binding 
affinity of this drug for this receptor subtype. This finding clearly suggest that the anti-secretory effect of PAS on GH-secreting adenoma cell cultures could be achieved via $\mathrm{SST}_{2}$.

Subsequently, the effect of OCT and PAS on GH secretion was tested in a large number of GH-secreting pituitary adenomas $(n=32)$ [128]. $\mathrm{SST}_{2}$ and $\mathrm{SST}_{5}$ (with the latter more expressed than $\mathrm{SST}_{2}$ ) were the prevalent subtype expressed in GH-secreting pituitary adenoma cells, and the treatment of primary cultures with $100 \mathrm{nM}$ OCT and PAS at different time-points ( 4 and $24 \mathrm{~h}$ ) demonstrated superimposable effects of the two drugs in reducing GH secretion. Similar to GH reduction, a comparable effect of both compounds in lowering $\left[\mathrm{Ca}^{++}\right] \mathrm{i}$, which is a pivotal second messenger involved in the regulation of hormone secretion, was reported, despite the number of OCT responsive samples (15/21) being slightly higher than samples responsive to PAS (11/21).

In another study, comparing 33 primary cultures derived from human somatotroph pituitary adenomas [129], GH levels after treatment with OCT and PAS were measured in correlation with the SST expression profile of each adenoma. In detail, OCT and PAS ( $10 \mathrm{nM}$ for $72 \mathrm{~h}$ ) demonstrated an overall comparable efficacy in GH reduction (36.8\% vs. $37.1 \%$, respectively). However, the analysis of a large number of samples allowed the authors to subdivide the adenomas in subgroups depending on their prevalent response to OCT or PAS, respectively. The PAS+ group, comprising six adenoma cultures $(18 \%)$, which showed a better response to PAS, and OCT+ group, in which five samples $(15 \%)$ showed a better response to OCT. $\mathrm{SST}_{2}$ and $\mathrm{SST}_{5}$ mRNA expression levels were correlated to the drug-dependent inhibition of GH release demonstrating, as expected, a significant positive correlation between $\mathrm{SST}_{2}$ expression and the anti-secretory activity of OCT. However, a slight, although not significant, trend of correlation was also found between $\mathrm{SST}_{2}$ expression and PAS-induced inhibition of GH secretion. Conversely, no correlation was found between $\mathrm{SST}_{5}$ expression and the anti-secretory effect of both drugs. The expression of $\mathrm{SST}_{2}$ as well as $\mathrm{SST}_{2} / \mathrm{SST}_{5}$ ratio, were significantly lower in PAS+ adenoma group, as compared to the other samples. However, among this group, higher amounts of $\mathrm{SST}_{2}$ mRNA were detected in the samples displaying $\geq 50 \%$ of GH inhibition, compared to samples with a lower response. Furthermore, a strong and direct correlation between the percentage of GH decrease induced by PAS and OCT was found by using a pairwise comparison of the different 33 adenoma cell cultures $(r=0.829, p<0.0001)$, which strengthens the observation of a prevalent involvement of SST2 in mediating the biological action of both OCT and PAS [129].

All these studies demonstrated an overall comparable efficacy of the two drugs in reducing GH levels in somatotropinomas in vitro. Moreover, based on direct evidence of a positive correlation between $\mathrm{SST}_{2}$ mRNA expression and PAS efficacy $[127,129]$, they highlighted a prevalent involvement of $\mathrm{SST}_{2}$ in the clinical effects, of both OCT and PAS.

Based on these results, several clinical trials aimed to evaluate the efficacy of PAS in acromegaly patients both medically naïve or non-responding to first generation SRLs (OCT and LAN), used as first-line medical treatment. A prospective, randomized, double-blind study compared OCT and PAS activity in 358 patients from 27 different countries [130], by enrolling medically naive acromegaly patients with $\mathrm{GH}>5 \mu \mathrm{g} / \mathrm{L}$ or $\mathrm{GH}$ nadir $\geq 1 \mu \mathrm{g} / \mathrm{L}$ after an oral glucose tolerance test (OGTT), and IGF-1 above the upper normal limit. Patients were treated with PAS LAR $40 \mathrm{mg} / 28$ days $(n=176)$ or OCT LAR $20 \mathrm{mg} / 28$ days $(n=182)$ for 12 months, which allows the possibility to increase the dose of both compounds (PAS LAR $60 \mathrm{mg}$ or OCT LAR $30 \mathrm{mg}$ ) after three and/or seven months, if GH values were $\geq 2.5 \mu \mathrm{g} / \mathrm{L}$ and/or IGF-1 remain above the upper limit of normality. The main endpoint was the achievement of biochemical control (GH $<2.5 \mu \mathrm{g} / \mathrm{L}$ and normal IGF-1) after the $12^{\text {th }}$ month. Results demonstrated that the percentage of patients who achieved biochemical control was higher in the PAS LAR treated group than in the OCT LAR group (31.3\% vs. $19.2 \%, p=0.007,35.8 \%$ vs. $20.9 \%$, when including patients with IGF-1 below the lower normal limit). In more detail, $38.6 \%$ and $48.3 \%$ of patients in the PAS LAR group achieved normal IGF-1 and GH $<2.5 \mu \mathrm{g}$ compared to $23.6 \%$ and $51.6 \%$, respectively, in the OCT LAR group $(p=0.002)$. Patients who did not achieve biochemical control (31.0\% of PAS LAR group and $22.2 \%$ of OCT LAR group) did not receive the recommended dose 
increase. The main adverse event was hyperglycemia, which shows a higher percentage of incidence in the PAS LAR group compared to the OCT LAR group (57.3\% vs. $21.7 \%$ ).

These results represent the first clear evidence of a higher efficacy of PAS LAR over OCT LAR, which allows PAS LAR to be considered a viable new treatment option for acromegaly [130].

In the same year, a randomized, clinical phase 3 trial comparing the effect of PAS with continued treatment with OCT or LAN in patients with inadequately controlled acromegaly (PAOLA study) was published [131]. Acromegalic patients, who were previously treated with $30 \mathrm{mg}$ long-acting OCT or $120 \mathrm{mg}$ LAN Autogel for $\geq 6$ months as monotherapy, who did not normalize GH and IGF-1 levels (5-point, $2 \mathrm{~h}$ of mean growth hormone concentration $>2.5 \mu \mathrm{g} / \mathrm{L}$, and IGF-1 concentration $>1.3$ times the upper normal limit) were enrolled, and stratified according to the previous treatment (OCT or LAN) and GH concentrations at screening $(2.5-10 \mu \mathrm{g} / \mathrm{L}$ and $>10 \mu \mathrm{g} / \mathrm{L})$. The patients were randomly assigned to PAS $40 \mathrm{mg}(n=65)$, PAS $60 \mathrm{mg}(n=65)$, or active control $(n=68)$ groups. After 24 weeks of treatment, 10 patients (15\%) in the PAS $40 \mathrm{mg}$ group and 13 patients $(20 \%)$ in the PAS $60 \mathrm{mg}$ group achieved biochemical control, which was not obtained in all the patients in the active control group. The most common adverse events were hyperglycemia $(n=21$ [33\%] for treatment with $40 \mathrm{mg}$ PAS, $n=19[31 \%]$ with $60 \mathrm{mg}$ PAS, and $n=9[14 \%]$ with active control) and diarrhea ( $n=10[16 \%], n=12$ $[19 \%]$, and $n=3[5 \%])$. Most were grade 1 or 2 in severity. Serious adverse events were reported in six $(10 \%)$ patients in the PAS $40 \mathrm{mg}$ group, two (3\%) in the PAS $60 \mathrm{mg}$ group, and three (5\%) in the active control group [131].

\subsection{Cushing's Disease}

The presence of ACTH-secreting pituitary adenoma in the anterior lobe of the pituitary gland is the primary cause of Cushing's disease (CD). In CD, the physiological negative feedback exerted by adrenal steroids is disrupted, which contributes to the autonomous ACTH hypersecretion from the adenoma. The resulting state of hypercortisolism is associated with peculiar clinical signs and symptoms and is correlated with a significant increase in patient morbidity and mortality [132].

When facing the challenge of the medical treatment of $C D$, it is well recognized that the ideal therapy should target the primary cause of the disease resulting in the control of hormone hypersecretion and reduction of the adenoma mass. This result still represents a "chimera" for clinicians and researchers, despite all the efforts and the different compounds developed and tested, especially in recent years [132].

Based on the well-recognized expression of SSTs on ACTH-secreting pituitary adenomas, first-generation SRLs, OCT, and LAN, were initially tested for the treatment of CD [133]. However, a lack of efficacy in suppressing both basal and CRH-stimulated ACTH secretion in patients was reported $[133,134]$, likely because $\mathrm{SST}_{2}$, which is the main target of OCT and LAN, is significantly down-regulated by high levels of glucocorticoids occurring during active CD [135]. However, since $\mathrm{SST}_{5}$ is the most predominantly expressed SST subtype in human ACTH-secreting pituitary adenomas and in other CD cell models such as murine AtT20 cell line [136]. Its expression is not influenced by exposure to high glucocorticoid levels $[137,138]$. PAS has been identified as the main candidate in the medical treatment of $C D$. Several preclinical studies compared the effects of PAS and OCT in CD models before and after its approval in clinical practice.

An in vitro "head-to head" study evaluated the effect of PAS and OCT on ACTH release by six primary cultures of human corticotroph cells, as well as their effect on AtT20 cells [105]. The SST expression profile demonstrated a predominant expression of $\mathrm{SST}_{5} \mathrm{mRNA}\left(>\mathrm{SST}_{2}\right)$ in all CD samples analyzed. As expected, treatment with $10 \mathrm{nM}$ PAS for $27 \mathrm{~h}$ was more effective than OCT in the inhibition of basal ACTH secretion. PAS significantly decreased ACTH secretion in three out of five primary cultures (30\% to $40 \%$ ), while OCT inhibited ACTH release in only one out of five cultures ( $28 \%$ suppression). Similar results were obtained in AtT20 cells, in which only PAS, but not OCT, was able to inhibit with high potency $\left(\mathrm{IC}_{50} 0.2 \mathrm{nM}\right.$ ) basal ACTH secretion [105]. Another detailed study used AtT20 cells to define the role of $\mathrm{SST}_{2}$ and $\mathrm{SST}_{5}$ in PAS and OCT-mediated inhibition of $\mathrm{ACTH}$ release, which reproduces the in vivo condition of glucocorticoids exposure observed during 
$\mathrm{CD}$ [137]. First, to better understand the role of $\mathrm{SST}_{5}$ in the inhibition of CRH-induced ACTH release, an experimental $\mathrm{SST}_{5}$-selective agonist (BIM-23268) was tested in addition to PAS, SRIF, and OCT, using culture conditions in the absence (basal condition) or presence of high levels of glucocorticoids. In basal conditions, PAS demonstrated a significantly higher potency $\left(\mathrm{IC}_{50} 0.06 \mathrm{nM}\right)$ than $\mathrm{OCT}\left(\mathrm{IC}_{50}\right.$ $0.2 \mathrm{nM}$ ) in reducing ACTH secretion. Pre-treatment of AtT20 cells with $10 \mathrm{nM}$ dexamethasone (DEX) led to a 20-fold decrease of OCT-induced inhibition of ACTH secretion $\left(\mathrm{IC}_{50}\right.$ from 0.2 to $4.3 \mathrm{nM}$ ) while it did not affect a PAS anti-secretory effect.

The analysis of SST mRNA profile after DEX exposure for $48 \mathrm{~h}$ demonstrated a down-regulation of $\mathrm{SST}_{2}(45 \%)$, while $\mathrm{SST}_{5}$ expression was not affected. This supports, at a molecular level, the persistent effects of PAS in these experimental conditions, as compared to OCT [137]. In this context, the $\mathrm{SST}_{5}$ preferential compound BIM-23268 was significantly more effective in reducing CRH-induced ACTH release after DEX pretreatment than in basal conditions ( $60 \%$ vs. $15 \%)$. This finding could be related to possible modifications of the interactions among SSTs, such as $\mathrm{SST}_{2} / \mathrm{SST}_{5}$ crosstalk, induced by high levels of glucocorticoids, as well as to a possible effect of DEX on the intracellular machinery, which leads to an enhanced activation of the anti-secretory pathway [114,133,136].

In 2009, Ben-Shlomo \& Coll. reported the effects of PAS, SRIF, and OCT, alone or in combination with selective receptor antagonists, on cAMP accumulation and intracellular $\mathrm{Ca}^{++}$oscillation [139]. Authors used wild-type (WT) and transfected AtT20 cells, which overexpressed human $\mathrm{SST}_{2}$ or $\mathrm{SST}_{5}$ [139]. In WT cells, a significantly higher inhibition of cAMP accumulation was induced by PAS, as compared to both SRIF and OCT (IC $50: 55 \mathrm{pM}, 370 \mathrm{pM}$, and $470 \mathrm{pM}$, for PAS, SRIF, and OCT, respectively), as well as a more effective suppression $\mathrm{Ca}^{++}$oscillation. However, different results were obtained in $\mathrm{SST}_{2}$ transfected cells, in which PAS was less effective in inducing cAMP reduction when compared to WT cells. As expected, co-treatment with the $\mathrm{SST}_{2}$-selective antagonist BIM-23454 did not affect PAS-induced cAMP reduction, which supports the evidence of a negligible involvement of

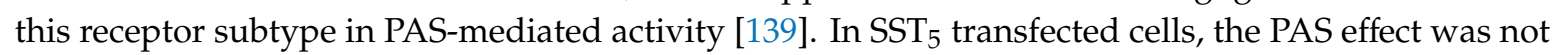
enhanced by the high expression of the receptor, likely because, in the WT-setting, $\mathrm{IC}_{50}$ was already in the picomolar range. However, it induced a sustained efficacy on cAMP reduction, which suggests that $\mathrm{SST}_{5}$ can play a role in preventing cells from desensitization of different SSTs.

More recently, van der Pas \& Coll. directly compared the efficacy of PAS and OCT on ACTH secretion in primary cultures of corticotroph pituitary adenomas from patients grouped according different levels of urinary free cortisol (UFC) measured before adrenalectomy [135]. In detail, they evaluated the effect of OCT and PAS on four primary cultures from patients with normal UFC levels before surgery, which demonstrates a significantly higher effect of PAS compared to OCT in inhibiting ACTH release in three out of four cell cultures (overall mean percent reduction: $49 \%$ vs. $26 \%$, respectively). Although almost all samples showed a prevalent expression of SST2 mRNA, at the protein level, SST5 was expressed more in two out of four samples. Then, authors evaluated the effect of PAS and OCT on ACTH secretion in cells from a patient nearly reaching normal UFC before surgery (UFC $1.06 \times$ ULN), which demonstrates that PAS was able to reduce ACTH levels at lower concentrations $\left(\mathrm{IC}_{50}: 0.2 \mathrm{nM}\right.$ ) than $\mathrm{OCT}$, supporting previous reports [105]. Conversely, $\mathrm{OCT}$ significantly decreased ACTH secretion only at relatively high concentrations $\left(\mathrm{IC}_{50} 39 \mathrm{nM}\right)$, which is in line with the results obtained by Ibáñez-Costa \& Coll. [128].

These results strengthen the hypothesis of a major role of $\mathrm{SST}_{5}$ in driving the anti-secretory activity of PAS in ACTH-secreting pituitary adenomas when compared to OCT, even in the presence of higher expression of $\mathrm{SST}_{2}$ than $\mathrm{SST}_{5}$ mRNA in tumor cells [135].

On the other hand, different results were obtained by Ibáñez-Costa \& Coll. who tested OCT and PAS on ACTH release and $\left[\mathrm{Ca}^{++}\right]$i kinetics in primary cultures of human corticotroph pituitary adenomas [128]. Treatments with 100nM OCT (three tumor samples) or PAS (four tumor samples) caused a significant ACTH reduction in two out of three tumors in the presence of high OCT concentrations, while only a slight ACTH reduction in two out of four samples was observed with PAS, despite a prevalent expression of $\mathrm{SST}_{5} \mathrm{mRNA}$ in all samples as compared to $\mathrm{SST}_{2} \mathrm{mRNA}$. The effect 
of OCT and PAS on $\left[\mathrm{Ca}^{++}\right]$i was evaluated in 10 and nine primary cultures, respectively. Although both drugs prevented an $\left[\mathrm{Ca}^{++}\right] \mathrm{i}$ increase in about $50 \%$ of primary cultures $(4 / 10$ and $5 / 9$, respectively), OCT was significantly more effective than PAS, as demonstrated by the proportion of responsive cells induced by the two compounds (56.1\% OCT vs. $12.9 \%$ PAS) [128]. A possible explanation of these discordant results could be related to the supra-physiological concentrations of OCT used in this study (10-fold higher to the estimated therapeutic dose), which could have partially activated $\mathrm{SST}_{5}$, over $\mathrm{SST}_{2}$, despite the lower affinity of OCT for the latter receptor.

Moreover, most of the primary cultures were obtained from $C D$ patients who underwent medical treatment before surgery and this condition could have caused an increase of SST2 mRNA levels, which leads to an $\mathrm{SST}_{2}$-related responsiveness [128]. However, the main pitfall concerning this study is related to the methodological setting of the experiments because these authors did not perform a head-to head comparison between OCT and PAS in the same cell culture, as in previous studies [105]. This experimental condition needs to be taken into account because the well-recognized inter-tumor heterogeneity of corticotroph pituitary adenomas, which could modify the responsiveness to medical treatments [140,141]. However, it is important to remark that all these data from preclinical studies were decisive for the approval of PAS as medical treatment for CD by both EMA and FDA.

In 2009, a multicenter Phase II clinical trial reported that PAS treatment decreased UFC levels and ACTH release in $76 \%$ of patients during a treatment period of 15 days [142]. The first phase 3 trial assessing PAS LAR in patients with CD was published in 2018 [143]. In this study, 150 patients with persistent, recurrent, or de-novo (non-surgical candidates) CD were enrolled: 74 patients $(49 \%)$ were treated with $10 \mathrm{mg}$ i.m. PAS LAR every four weeks for 12 months and 76 patients (51\%) with $30 \mathrm{mg}$. The primary efficacy endpoint (mUFC normalization) was met by 31 out of 74 patients $(41.9 \%$ [95\% CI 30.5-53.9]) in the $10 \mathrm{mg}$ group and 31 out of 76 patients (40.8\% [29.7-52.7]) in the $30 \mathrm{mg}$ group. Authors concluded that long-acting intramuscular PAS LAR displays a similar efficacy than the twice-daily subcutaneous injections, with positive responses in about $40 \%$ of patients with $C D$, which provides a convenient monthly administration schedule.

Lastly, a very recent study by Pivonello \& Coll. evaluated the efficacy and safety of PAS treatment, according to the real-world evidence [144]. This study, performed on 23 CD patients, demonstrated that, in the real-life clinical practice, a six-month treatment with PAS normalizes, or nearly normalizes, UFC in about $68 \%$ of patients with a very mild to moderate disease. In line with the previously described clinical studies, the main adverse event was the induction or worsening of glucose imbalance, which confirms the usefulness of this treatment in patients with mild disease, without uncontrolled diabetes.

\subsection{Other Pituitary Tumors}

Because other pituitary adenomas, such as prolactinomas, TSH-secreting and FSH-secreting adenomas and non-functioning pituitary adenomas (NFPAs) express different SST subtypes besides $\mathrm{SST}_{2}$ and $\mathrm{SST}_{5}$, and/or other GPCRs, such as D2R. Additional medical treatments are used in these tumors (e.g., D2R-preferential drugs, such as cabergoline, in prolactinomas). Moreover, pituitary tumors such as TSH-secreting and FSH-secreting adenomas are very rare. Therefore, only a few studies evaluated the effects of OCT and PAS in these tumors.

Ibáñez-Costa \& Coll., in the previously mentioned study [128], compared the effect of OCT and PAS in four primary cultures of prolactinomas and in 28 NFPAs measuring $\left[\mathrm{Ca}^{++}\right] \mathrm{i}$ and cell viability.

Primary cultures were established from prolactinomas, which displayed in vivo resistance to cabergoline treatment. Analysis of the SST profile demonstrated high levels of SST 1 associated with a low expression of the other SSTs. Treatment of cells with OCT and PAS showed a poor effect on $\left[\mathrm{Ca}^{++}\right] \mathrm{i}$ of both SRLs: OCT decreased $\left[\mathrm{Ca}^{++}\right]$i in two out of four cultures, but only in $7.0 \%$ of the cells, while PAS failed to induce appreciable effects. Both SRLs decreased cell viability in one-third of tumors after 48 to $72 \mathrm{~h}$.

As far as NFPAs, the SST expression profile demonstrated a high expression of $\mathrm{SST}_{3}$, followed by $\mathrm{SST}_{2}, \mathrm{SST}_{5}, \mathrm{SST}_{1}$, and $\mathrm{SST}_{4}$, which suggests a possible prevalent effect of PAS compared to OCT. 
Despite SST expression profile, both compounds showed a poor effect on $\left[\mathrm{Ca}^{++}\right]$i kinetics inhibition even though OCT was slightly more effective than PAS in an isolated subset of cells [128]. Discordant results were obtained in the evaluation of cell viability. NFPA primary cultures differently responded to OCT and PAS treatment showing a slight and no significant decrease in cell viability after treatment with OCT (5/16 cell cultures after $24 \mathrm{~h}, 2 / 8$ after $48 \mathrm{~h}$, and 2/7 after $72 \mathrm{~h})$, as well as with PAS (4/15 cell cultures after $24 \mathrm{~h}, 1 / 7$ after $48 \mathrm{~h}$, and $1 / 4$ after $72 \mathrm{~h}$ ). Conversely, a moderate significant increase in cell viability was induced by treatment with OCT when compared to untreated cells in 11/16 cell cultures after $24 \mathrm{~h}$, in $5 / 8$ cell cultures after $48 \mathrm{~h}$, and in $2 / 6$ cell cultures after $72 \mathrm{~h}$. Similarly, to OCT, PAS increased cell viability in in 11/15 NFPA cell cultures after $24 \mathrm{~h}$, in $6 / 7$ after $48 \mathrm{~h}$, and in 3/4 after $72 \mathrm{~h}$.

In three TSH-secreting pituitary adenoma primary cultures, the $\mathrm{SST}_{2} / \mathrm{SST}_{5}$ expression ratio was predictive of the hormonal and cell viability effects of OCT, likely due to the prevention of tachyphylaxis. However, the association of D2R agonists to SRLs could prevent the pharmacological escape [145].

To sum up, based on preclinical evidence, we can reasonably state that OCT and PAS can alternatively act by activating $\mathrm{SST}_{2}$ and/or $\mathrm{SST}_{5}$ depending on the specific tumor cell type. Indeed, as expected, OCT is mainly effective in $\mathrm{SST}_{2}$-expressing GH-secreting cells as well PAS in $\mathrm{SST}_{5}$-expressing tumor corticotroph cells. However, a number of results showed that PAS is also able to inhibit GH secretion in somatotropinomas by activating $\mathrm{SST}_{2}$, despite its prevalent affinity for $\mathrm{SST}_{5}$. Similarly, high doses of OCT can act through the activation of SST $\mathrm{S}_{5}$ in some corticotropinomas, which highly expresses this receptor subtype.

Figure 3 summarizes all the reported data as far as the effects of OCT and PAS on pituitary adenomas, in relationship with the SST profile evidenced in the respective study.

\begin{tabular}{|c|c|c|c|}
\hline Pituitary adenoma histotypes & $\begin{array}{c}\text { Efficacy/potency } \\
\text { OCT ys. PAS }\end{array}$ & \multicolumn{2}{|c|}{ SST expression } \\
\hline Somatotroph adenomas & GH secretion & $m R N A$ & protein \\
\hline Bruns et al. $(2002)^{\mathrm{a}}[100]$ & & \multirow[t]{5}{*}{-} & \multirow{5}{*}{$\begin{array}{l} \\
- \\
- \\
-\end{array}$} \\
\hline Murray et al. (2004) [126] & & & \\
\hline Hofland et al. (2004) [127] & & & \\
\hline Ibáñez-Costa A. et al. $(2016)^{b}[128]$ & & & \\
\hline Gatto et al. (2017) [129] & & & \\
\hline Corticotroph adenomas & ACTH secretion $/{ }^{*} c A M P$ & & \\
\hline Hofland et al. (2005) [105] & \multirow{5}{*}{ I } & \multirow{4}{*}{ - } & \multirow{3}{*}{$\begin{array}{l}- \\
- \\
-\end{array}$} \\
\hline Van der Hoek et al. $(2005)^{\mathrm{c}, \mathrm{d}}$ [137] & & & \\
\hline Ben-Shlomo et al. (2009)*:c [139] & & & \\
\hline van der Pas et al. (2013) $[135]$ & & & 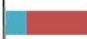 \\
\hline Ibáñez-Costa et al. $(2016)^{b}[128]$ & & & - \\
\hline Prolactinomas & {$\left[\mathrm{Ca}^{2+}\right]_{i}$} & & \\
\hline Ibáñez-Costa et al. $(2016)^{\mathfrak{b}}[128]$ & unsettled & 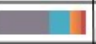 & - \\
\hline Non-functioning pituitary adenomas & {$\left[\mathrm{Ca}^{2+}\right]_{i}$} & & \\
\hline Ibáñez-Costa et al. $(2016)^{b}$ [128] & & 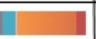 & - \\
\hline
\end{tabular}

Figure 3. Differential effects of OCT and PAS on pituitary adenomas, in relationship with the SST profile. In the left column, blue $=$ OCT and green $=$ PAS. In the right column, light blue $=$ SST2, red $=$ SST5, grey $=$ SST1, and orange $=$ SST3. cAMP, intracellular cAMP level. $\left[\mathrm{Ca}^{2+}\right] \mathrm{i}$, intracellularcalciumconcentration .

${ }^{a} \mathrm{GH}$ release by primary cultures of rat anterior pituitary cells, after $6 \mathrm{~h}$ of treatment. ${ }^{\mathrm{b}}$ Data extracted from graphs presented in the related article. ${ }^{c}$ Study carried out using the AtT20 cell line. ${ }^{\mathrm{d}}$ Effect of OCT and PAS on CRH-induced ACTH release after pre-treatment with DEX and mRNA expression after $24-48 \mathrm{~h}$ of DEX. ${ }^{\mathrm{e}}$ Primary cultures from patients with normalized urinary-free cortisol. * Studies in which changes in cAMP accumulation in response to OCT or PAS was analyzed. 


\section{Comparison between First- and Second-Generation Somatostatin Receptor Ligands in Neuroendocrine Neoplasms}

Neuroendocrine neoplasms (NENs) comprise clinically and biologically heterogeneous tumors, originating from neuroendocrine cells disseminated in different organs (e.g., pancreas, stomach, lung, and colon) [146]. The most common NENs occur in the gastrointestinal tract or pancreas (GEP-NEN) and bronchopulmonary system [147], with an incidence increasing over the years, likely due to more efficient diagnostic tools [148]. Regardless of the anatomic origin, NENs include neuroendocrine carcinomas (NECs), characterized by poor differentiation and high-proliferation rate, and neuroendocrine tumors (NETs), well-differentiated and low-proliferating lesions, whose metastatic potential depends on tumor type, localization, and grade. By means of Ki-67 index and mitotic count, WHO 2017 classification grades NENs as: low-grade NET G1 (Ki-67 <3\%, mitotic index <2/10 hpf), NET G2 (Ki67 3-20\% or mitotic index 2-20/10 hpf), while NECs are by definition G3 (Ki67 index $>20 \%$ or mitotic index $>20 / 10$ hpf). G3 pancreatic NENs include both differentiated low proliferating NETs and undifferentiated aggressive small or large cell NECs [149]. These grading parameters reflect biologic aggressiveness of NENs and have prognostic and therapeutic relevance. NETs are also divided in two subgroups: (i) non-functioning tumors, which are the most common and do not secrete detectable levels of hormones with no or non-specific clinical symptoms [150], (ii) functioning tumors whose hormone hypersecretion leads to distinct signs of disease (flushing, diarrhea, hypoglycemia, hyperglycemia, peptic ulcers, etc.), and express biomarkers of neuroendocrine differentiation such as chromogranin A (CgA) and synaptophysin [151], as well as peptide hormones.

Furthermore, a specific staging system has been developed for GEP-NENs, which is the classic tumor/node/metastasis (TNM) classification and a clinical staging for mortality risk assessment based on the anatomical extent of NEN [152]. This is useful for decision-making regarding treatment.

The great majority of GEP-NENs, as well as approximately $50 \%$ of small intestine NETs and insulinomas, express multiple SST subtypes involved in hormone secretion and tumor cell growth. $\mathrm{SST}_{2}$ expression is predominant, followed by $\mathrm{SST}_{5}$, while $\mathrm{SST}_{1}, \mathrm{SST}_{3}$, and SST4 are scarcely detected, even if a great variability among NET types and localization was observed [153-155]. Moreover, molecular investigation revealed that pNETs also express a truncated splice variant of the SST5 (SST5TMD4) [156]. In GEP-NEN, $\mathrm{SST}_{2}$ expression is inversely correlated with grading and patient outcome, as well as the expression of the chemokine receptor CXCR4 [153,157]. Similarly to SSTs, CXCR4 is often present in highly proliferative and advanced tumors of various origin, and the chemokine-receptor system CXCL12-CXCR4 largely influences neuroendocrine regulation and functions $[158,159]$. It may represent an additional diagnostic and therapeutic target in NENs [160].

\subsection{Somatostatin Receptor Ligands in Preclinical Models of Neuroendocrine Neoplasms}

The small incidence and large heterogeneity of NENs, along with inadequate availability of disease experimental models, often prevents a satisfactory preclinical and translational research. Nevertheless, knowledge of molecular alterations associated with NEN pathogenesis and progression (e.g., activation of mTOR signaling and tyrosine kinase activity of PDGFR and VEGFR) has improved over recent years, by favoring the identification of targeted drugs such as everolimus [161] and sunitinib [162], which currently are complementary to SRLs as medical management of NET clinical symptoms [19].

The paucity of NEN-derived cell lines (the two most used are the human pancreatic carcinoid cell, BON-1, and the human pancreatic islet cell carcinoma cell line, QGP-1, which show mutations in accordance with those detected in sporadic pNET patients) [163], and the technical issues in the establishment of patient-derived primary cultures and xenografts, makes preclinical research difficult to adequately recapitulate in vitro NET disease. Moreover, the usefulness of cell lines as a model for studying NEN responses to SRLs is debatable.

First, the in vitro activity of OCT was tested in BON-1 cells, which express $\mathrm{SST}_{1}, \mathrm{SST}_{2}$, and $\mathrm{SST}_{5}$ : OCT inhibited cAMP accumulation, CgA secretion, and MAP kinase activity [164], Akt-phosphorylation and cell growth [36], and tumor growth [165]. On the contrary, other studies reported the lack of 
significant anti-proliferative effects in both BON-1 and QG-1 cells $[166,167]$ neither in 2D cultures nor in 3D-spheroid models [168], as well as in mice bearing BON-1 xenografts [166]. The BON-1 cell line has been also proposed as a model mimicking the IGF system on GEP-NETs and a model used to test the activation of IGF-related factors upon treatment with OCT and PAS [169].

OCT also failed to exert anti-proliferative activity in the most frequently used NET cell lines, which showed $\mathrm{SST}_{2}$ expression levels lower than observed in human NEN tissues [165]. Overall, the lack of SRL effects might be explained by: (i) low $\mathrm{SST}_{2}$ expression in BON-1 and other cell lines, (ii) limited similarity of GEP-NET cell lines with a tumor phenotype, and (iii) cancer-associated mutations occurred in cell cultures [170]. This implies a careful extrapolation of results, which encourages a shift to patient-derived cultures and xenografts.

The NET cell line QGP-1 was also used to analyze $\mathrm{SST}_{2}$ domains regulating receptor trafficking and signal transduction: the treatment with the $\mathrm{SST}_{2}$-specific analog BIM23120 caused $\mathrm{SST}_{2}$ desensitization and internalization, which possibly explains SRL resistance detected in vivo after prolonged treatment with $\mathrm{SST}_{2}$ preferential compounds [171].

A better understanding of SRL effects was obtained after isolation and characterization of primary NET cultures. Cell cultures from 15 human pNETs were shown to retain in vitro SST expression profile (predominantly $\mathrm{SST}_{2}$ ) and a secretory phenotype $(\mathrm{CgA})$ of the original tumor, and were used to explore and compare the biological activity of OCT and PAS [117]. OCT reduced both cell viability and CgA release via SST2 activation, which, however, rapidly results in prolonged receptor internalization. On the contrary, PAS, which similarly exerts anti-proliferative and anti-secretory effects but does not phosphorylate $\mathrm{SST}_{2}$, induced a fast and transient receptor internalization/membrane trafficking cycle. Therefore, primary cultures explain clinical observations of tachyphylaxis induced by OCT in GEP-NET patients $[117,172,173]$, together with modulation of downstream pathways [173]. The observation of a lower desensitization induced by PAS might imply that its activation of $\mathrm{SST}_{5}$ stabilizes $\mathrm{SST}_{2}$ at the cell membrane, which forms a heterodimer that sustains long-lasting efficacy of SRLs.

Human pNET primary cultures were also used to test the possible synergism as far as the anti-tumor and anti-secretory activity of SRLs and everolimus [174], which is a mTOR inhibitor approved for advanced pancreatic, gastrointestinal, and lung NETs [175], to elucidate possible mechanisms at the basis of disappointing efficacy and resistance occurrence observed in patients. Everolimus inhibited CgA production and cell viability, but co-treatment with SRLs neither improved its efficacy nor circumvented everolimus-dependent Akt activation [174]. Again, the primary culture model closely mimics the lack of synergistic/additive anti-tumor effects of SRLs in combination with everolimus, as observed for overall survival in patients. Mutations and alterations of the mTOR pathway in subsets of NETs [176,177] as well as preclinical efficacy of everolimus in NET cell lines [166,177-180] were extensively reported, and provided the rationale for mTOR inhibitor therapy. However, remarkable clinical benefits were limited and still debated [181]. mTOR inhibition leads to multiple compensatory pro-survival signals (e.g., activation ERK1/2 and PI3K/Akt pathways) [181], which could explain everolimus resistance as reported in primary NET cultures [174].

\subsection{Somatostatin Receptor Ligands in Clinical Management of Neuroendocrine Neoplasms: Improvement of Symptoms and Anti-tumor Effects}

Due to NENs heterogeneity, multimodal treatment strategies such as surgery, systemic pharmacological treatment, and radiotherapy are used to control clinical symptoms due to hypersecretion and tumor growth, and to delay disease progression [182]. Although surgery represents the first line treatment of NENs, a high percentage of tumors is not surgically resectable because of their metastatic condition at the time of initial diagnosis (mainly small intestine and pNETs). In this condition, the use of medical treatment represents the main tool to control tumor-related symptoms and to prolong patient survival.

First line systemic treatment of well differentiated, locally advanced or metastatic NETs consist of SRLs (OCT LAR and LAN Autogel). Alpha-interferon and targeted drugs, such as everolimus, sunitinib, and bevacizumab, an anti-VEGFA antibody, or other tyrosine kinase receptor targeting 
antibodies and small molecules [183], are additional treatment options. Chemotherapy for advanced poorly or well differentiated NETs with a high-tumor burden [184].

GEP-NET patients progressing or recurring after failure of initial therapies have limited treatment options. Therefore, peptide receptor radionuclide therapy (PRRT) with SRL-based ${ }^{177}$ Lu-DOTATATE, ${ }^{90}$ Y-DOTATATE, or ${ }^{90}$ Y-DOTATOC could be further treatment options [185]. G1 and G2 NENs satisfactorily respond to PRRT, while the response in G3 NENs is still unclear. Therefore, guidelines for G3 NECs did not recommend radiopharmaceutical therapy [186,187].

OCT and LAN (both immediate-release and long-acting formulations) are the standard of care for functioning and non-functioning NETs $[182,188]$ to control severe symptoms (diarrhea and flushing, carcinoid syndromes) associated with hypersecretion of serotonin, and pancreatic islet cell hormonal-secretory syndromes sustained by gastrin, glucagon, insulin, vasoactive intestinal peptide (VIP), and parathyroid hormone-related peptide [189].

First-generation SRLs have been widely demonstrated to control symptoms in patients with NETs [190-192]. Anti-tumor efficacy, as well as time to tumor progression, was prolonged from 6 to 14.3 months, which was observed with OCT LAR in the PROMID Phase 3 study analyzing metastatic midgut NETs [24], and significant increases in PFS was reported in LAN Autogel-treated patients entered in the placebo-controlled Phase 3 CLARINET trial [23]. These results encouraged FDA and EMA approvals for clinical use in GEP-NETs. Both OCT and LAN are highly effective in managing carcinoid symptoms [189], which shows an increase in patients' PFS [27] and good tolerability [193].

The response to SRL treatment in terms of inhibition of secretion and tumor growth is extremely variable among NEN patients, likely due to both inter-tumor variability and differences in the development of resistance to therapy, besides pharmacological properties of SRLs (biased agonistic activity). After prolonged treatments with first generation SRLs, GEP-NET patients often exhibit inadequate control of symptoms due to hormonal overproduction at conventional doses. Therefore, resistance due to tachyphylaxis is a frequent clinical problem [194]. Several mechanisms underlying SRL resistance have been proposed including $\mathrm{SST}_{2}$ downregulation/internalization or stabilization/degradation [172,173], as previously discussed, and changes in SST signaling/functioning and upregulation of proliferative genes [195]. At least initially, higher doses successfully counteract the loss of susceptibility to SRLs, which allows an adequate disease control and maintains good tolerability. However, the outcome in terms of PFS and overall survival (OS) with the escalation-dose are still unclear [196].

Preclinical studies, showing the lower impact of PAS on $\mathrm{SST}_{2}$ phosphorylation, internalization, and recycling [104,117], suggested the potential of this agent to overcome tachyphylaxis and prolong the response. OCT LAR-refractory GEP-NET patients treated with PAS achieved a satisfactory relief of diarrhea and flushing ( $30 \%$ of patients) and tolerability in a Phase II study [197]. Subsequently, a Phase 3 trial in advanced and symptomatic patients after SRL treatment exploring the efficacy of PAS did not show benefits when compared to high doses of OCT LAR [198].

PAS is not routinely used in the treatment of NETs since the evidence of efficacy of this drug in patients progressing after OCT or LAN treatments is still scanty and rather controversial [198,199], even in escalated-doses studies [200]. In addition, the frequent occurrence of hyperglycemia $(\sim 80 \%$ of patients) observed with this drug [201], likely due to the effect of SST $_{5}$-mediated reduction of insulin production by pancreatic $\beta$-cells, makes its risk/benefit profile questionable. Further studies will help clarify the reliability of PAS, alone or in combination with other agents [199,202], in the management of NETs.

In summary, currently OCT LAR and LAN Autogel remain the cornerstone of systemic therapy for NETs, either alone, or in combination with other targeted therapies [203]. Advances in the knowledge of the SST pathways, which are molecular and microenvironmental mediators relevant for the pathogenesis of these tumors, will be crucial to discover novel therapeutic targets and improve anti-proliferative efficacy and safety of the drugs currently used in the management of NENs. 


\section{Conclusions and Future Perspectives}

First-generation SRLs (OCT and LAN) primarily differ from the second-generation SRL (PAS), for their peculiar membrane receptor binding affinity. While OCT and LAN are mainly $\mathrm{SST}_{2}$-preferential ligands, PAS shows high binding affinity for multiple receptor subtypes (predominantly $\mathrm{SST}_{5}, \mathrm{SST}_{2}$, and $\mathrm{SST}_{3}$ ). However, a number of preclinical studies published in the last decade have demonstrated that the differences between first-generation and second-generation compounds go far beyond the mere SST binding affinity. In most reports, PAS showed a peculiar pattern of receptor phosphorylation, likely due to the activation of ligand-specific changes in receptor conformation. Therefore, PAS treatment results in a specific activation of intracellular pathways, as well as in a peculiar target-receptor internalization and trafficking compared to both OCT and native SRIF, mainly when evaluating $\mathrm{SST}_{2}$ (the SST mostly expressed in the majority of pituitary adenomas and NENs).

However, these observations mainly result from preclinical studies carried out on transfected cell models, which do not always represent reliable models for pituitary adenomas and NENs. Furthermore, evidence from data collected using tumor primary cultures suggests that the biological effects of a pan-ligand such as PAS may also vary depending on the specific tumor type. This hypothesis is supported by the evaluation of studies carried out on somatotroph and corticotroph adenomas. While in GH-secreting pituitary cells, PAS seems to act mainly via $\mathrm{SST}_{2}$. Its effect is predominantly exerted through $\mathrm{SST}_{5}$ in corticotroph cells. Of note, the biased-agonist effect observed after PAS binding to $\mathrm{SST}_{2}$ in transfected cell models has not been confirmed when using cells from somatotroph primary cultures, which endogenously express the receptors and represents a more reliable preclinical model of acromegaly. On the other hand, the higher potency and efficacy of PAS, in comparison to both OCT and LAN when targeting $\mathrm{SST}_{5}$ in transfected cell models is confirmed by preclinical evidence on human corticotroph adenoma cells (mainly expressing $\mathrm{SST}_{5}$ ). Although it was not formally demonstrated, these discrepancies observed in different cell types might also reflect the general receptor profile of the cells, which included the presence of receptors other than SSTs that can influence the SRL responses due to heterodimerization pathways. Further studies are warranted to address this issue.

In conclusion, data published so far demonstrate that, despite the initial aim to generate a drug with a universal binding profile for SSTs with biological characteristics similar to that of native SRIF, the second-generation SRL PAS shows cell and tissue specific properties that are not completely understood yet. In our opinion, future research studies should aim to go deeper and investigate the peculiar biological mechanisms activated by PAS (in comparison to first-generation SRLs) in preclinical models that are able to closely mimic the behavior of NEN in vivo. Although we are aware that this represents a huge challenge for the scientific community, some steps forward have been achieved in recent years (i.e., zebrafish xenografts, identification of pituitary adenoma cell hierarchy $[204,205])$, and new tools may help reach these goals).

Author Contributions: All Authors contributed to collect, select and analyze relevant scientific literature, and to wrote and revise the article.

Funding: This study was partially supported by grant from Italian Minister of Instruction, University and Research (PRIN 2017Z3N3YC) to DF.

Conflicts of Interest: The authors declare no conflicts of interest.

\section{References}

1. Reichlin, S. Somatostatin. New Engl. J. Med. 1983, 309, 1495-1501. [CrossRef] [PubMed]

2. Gunther, T.; Tulipano, G.; Dournaud, P.; Bousquet, C.; Csaba, Z.; Kreienkamp, H.J.; Lupp, A.; Korbonits, M.; Castano, J.P.; Wester, H.J.; et al. International Union of Basic and Clinical Pharmacology. CV. Somatostatin Receptors: Structure, Function, Ligands, and New Nomenclature. Pharm. Rev. 2018, 70, 763-835. [CrossRef] [PubMed] 
3. Barbieri, F.; Bajetto, A.; Pattarozzi, A.; Gatti, M.; Wurth, R.; Thellung, S.; Corsaro, A.; Villa, V.; Nizzari, M.; Florio, T. Peptide receptor targeting in cancer: The somatostatin paradigm. Int. J. Pept. 2013, 2013, 926295. [CrossRef] [PubMed]

4. Theodoropoulou, M.; Stalla, G.K. Somatostatin receptors: From signaling to clinical practice. Front. Neuroendocr. 2013, 34, 228-252. [CrossRef] [PubMed]

5. Ferone, D.; van Hagen, P.M.; van Koetsveld, P.M.; Zuijderwijk, J.; Mooy, D.M.; Lichtenauer-Kaligis, E.G.; Colao, A.; Bogers, A.J.; Lombardi, G.; Lamberts, S.W.; et al. In vitro characterization of somatostatin receptors in the human thymus and effects of somatostatin and octreotide on cultured thymic epithelial cells. Endocrinology 1999, 140, 373-380. [CrossRef]

6. Ten Bokum, A.M.; Hofland, L.J.; van Hagen, P.M. Somatostatin and somatostatin receptors in the immune system: A review. Eur. Cytokine Netw. 2000, 11, 161-176. [PubMed]

7. McIntosh, C.H. Gastrointestinal somatostatin: Distribution, secretion and physiological significance. Life Sci. 1985, 37, 2043-2058. [CrossRef]

8. Artinian, J.; Lacaille, J.C. Disinhibition in learning and memory circuits: New vistas for somatostatin interneurons and long-term synaptic plasticity. Brain Res. Bull. 2018, 141, 20-26. [CrossRef]

9. Schettini, G.; Florio, T.; Magri, G.; Grimaldi, M.; Meucci, O.; Landolfi, E.; Marino, A. Somatostatin and SMS 201-995 reverse the impairment of cognitive functions induced by cysteamine depletion of brain somatostatin. Eur. J. Pharm. 1988, 151, 399-407. [CrossRef]

10. Tuboly, G.; Vecsei, L. Somatostatin and cognitive function in neurodegenerative disorders. Mini Rev. Med. Chem. 2013, 13, 34-46. [CrossRef]

11. Saito, T.; Iwata, N.; Tsubuki, S.; Takaki, Y.; Takano, J.; Huang, S.M.; Suemoto, T.; Higuchi, M.; Saido, T.C. Somatostatin regulates brain amyloid beta peptide Abeta42 through modulation of proteolytic degradation. Nat. Med. 2005, 11, 434-439. [CrossRef]

12. Schmid, L.C.; Mittag, M.; Poll, S.; Steffen, J.; Wagner, J.; Geis, H.R.; Schwarz, I.; Schmidt, B.; Schwarz, M.K.; Remy, S.; et al. Dysfunction of Somatostatin-Positive Interneurons Associated with Memory Deficits in an Alzheimer's Disease Model. Neuron 2016, 92, 114-125. [CrossRef]

13. Shenoy, P.A.; Kuo, A.; Khan, N.; Gorham, L.; Nicholson, J.R.; Corradini, L.; Vetter, I.; Smith, M.T. The Somatostatin Receptor-4 Agonist J-2156 Alleviates Mechanical Hypersensitivity in a Rat Model of Breast Cancer Induced Bone Pain. Front. Pharm. 2018, 9, 495. [CrossRef]

14. Riedemann, T. Diversity and Function of Somatostatin-Expressing Interneurons in the Cerebral Cortex. Int. J. Mol. Sci. 2019, 20. [CrossRef]

15. De Lecea, L. Cortistatin-functions in the central nervous system. Mol. Cell. Endocrinol. 2008, 286, 88-95. [CrossRef]

16. Ruscica, M.; Arvigo, M.; Steffani, L.; Ferone, D.; Magni, P. Somatostatin, somatostatin analogs and somatostatin receptor dynamics in the biology of cancer progression. Curr. Mol. Med. 2013, 13, 555-571. [CrossRef]

17. Brazeau, P.; Vale, W.; Burgus, R.; Ling, N.; Butcher, M.; Rivier, J.; Guillemin, R. Hypothalamic polypeptide that inhibits the secretion of immunoreactive pituitary growth hormone. Science 1973, 179, 77-79. [CrossRef]

18. Bauer, W.; Briner, U.; Doepfner, W.; Haller, R.; Huguenin, R.; Marbach, P.; Petcher, T.J. SMS 201-995: A very potent and selective octapeptide analogue of somatostatin with prolonged action. Life Sci. 1982, 31, 1133-1140. [CrossRef]

19. Barbieri, F.; Albertelli, M.; Grillo, F.; Mohamed, A.; Saveanu, A.; Barlier, A.; Ferone, D.; Florio, T. Neuroendocrine tumors: Insights into innovative therapeutic options and rational development of targeted therapies. Drug Discov. Today 2014, 19, 458-468. [CrossRef]

20. Florio, T. Molecular mechanisms of the antiproliferative activity of somatostatin receptors (SSTRs) in neuroendocrine tumors. Front. Biosci. A J. Virtual Libr. 2008, 13, 822-840. [CrossRef]

21. Ben-Shlomo, A.; Liu, N.A.; Melmed, S. Somatostatin and dopamine receptor regulation of pituitary somatotroph adenomas. Pituitary 2017, 20, 93-99. [CrossRef]

22. Merola, E.; Panzuto, F.; Delle Fave, G. Antiproliferative effect of somatostatin analogs in advanced gastroentero-pancreatic neuroendocrine tumors: A systematic review and meta-analysis. Oncotarget 2017, 8 , 46624-46634. [CrossRef]

23. Caplin, M.E.; Pavel, M.; Cwikla, J.B.; Phan, A.T.; Raderer, M.; Sedlackova, E.; Cadiot, G.; Wolin, E.M.; Capdevila, J.; Wall, L.; et al. Lanreotide in metastatic enteropancreatic neuroendocrine tumors. New Engl. J. Med. 2014, 371, 224-233. [CrossRef] 
24. Rinke, A.; Muller, H.H.; Schade-Brittinger, C.; Klose, K.J.; Barth, P.; Wied, M.; Mayer, C.; Aminossadati, B.; Pape, U.F.; Blaker, M.; et al. Placebo-controlled, double-blind, prospective, randomized study on the effect of octreotide LAR in the control of tumor growth in patients with metastatic neuroendocrine midgut tumors: A report from the PROMID Study Group. J. Clin. Oncol. 2009, 27, 4656-4663. [CrossRef]

25. Hasskarl, J.; Kaufmann, M.; Schmid, H.A. Somatostatin receptors in non-neuroendocrine malignancies: The potential role of somatostatin analogs in solid tumors. Future Oncol. 2011, 7, 895-913. [CrossRef]

26. Keskin, O.; Yalcin, S. A review of the use of somatostatin analogs in oncology. OncoTargets Ther. 2013, 6, 471-483.

27. Michael, M.; Garcia-Carbonero, R.; Weber, M.M.; Lombard-Bohas, C.; Toumpanakis, C.; Hicks, R.J. The Antiproliferative Role of Lanreotide in Controlling Growth of Neuroendocrine Tumors: A Systematic Review. Oncologist 2017, 22, 272-285. [CrossRef]

28. Smitha, M.C.; Maggi, M.; Orlando, C. Somatostatin receptors in non-endocrine tumours. Dig. Liver Dis. 2004, 36, S78-S85. [CrossRef]

29. Law, S.F.; Yasuda, K.; Bell, G.I.; Reisine, T. Gi alpha 3 and G (o) alpha selectively associate with the cloned somatostatin receptor subtype SSTR2. J. Biol. Chem. 1993, 268, 10721-10727.

30. Hershberger, R.E.; Newman, B.L.; Florio, T.; Bunzow, J.; Civelli, O.; Li, X.J.; Forte, M.; Stork, P.J. The somatostatin receptors SSTR1 and SSTR2 are coupled to inhibition of adenylyl cyclase in Chinese hamster ovary cells via pertussis toxin-sensitive pathways. Endocrinology 1994, 134, 1277-1285. [CrossRef]

31. Patel, Y.C.; Greenwood, M.T.; Warszynska, A.; Panetta, R.; Srikant, C.B. All five cloned human somatostatin receptors (hSSTR1-5) are functionally coupled to adenylyl cyclase. Biochem. Biophys. Res. Commun. 1994, 198, 605-612. [CrossRef]

32. Yasuda, K.; Rens-Domiano, S.; Breder, C.D.; Law, S.F.; Saper, C.B.; Reisine, T.; Bell, G.I. Cloning of a novel somatostatin receptor, SSTR3, coupled to adenylylcyclase. J. Biol. Chem. 1992, 267, 20422-20428.

33. Scherubl, H.; Hescheler, J.; Riecken, E.O. Molecular mechanisms of somatostatin's inhibition of hormone release: Participation of voltage-gated calcium channels and G-proteins. Horm. Metab. Res. Suppl. Ser. 1993, 27, 1-4.

34. Yatani, A.; Birnbaumer, L.; Brown, A.M. Direct coupling of the somatostatin receptor to potassium channels by a G protein. Metab. Clin. Exp. 1990, 39, 91-95. [CrossRef]

35. Schettini, G.; Florio, T.; Meucci, O.; Landolfi, E.; Grimaldi, M.; Ventra, C.; Marino, A. Somatostatin inhibition of adenylate cyclase activity in different brain areas. Brain Res. 1989, 492, 65-71. [CrossRef]

36. Charland, S.; Boucher, M.J.; Houde, M.; Rivard, N. Somatostatin inhibits Akt phosphorylation and cell cycle entry, but not p42/p44 mitogen-activated protein (MAP) kinase activation in normal and tumoral pancreatic acinar cells. Endocrinology 2001, 142121-142128. [CrossRef]

37. Florio, T.; Yao, H.; Carey, K.D.; Dillon, T.J.; Stork, P.J. Somatostatin activation of mitogen-activated protein kinase via somatostatin receptor 1 (SSTR1). Mol. Endocrinol. 1999, 13, 24-37. [CrossRef]

38. Pages, P.; Benali, N.; Saint-Laurent, N.; Esteve, J.P.; Schally, A.V.; Tkaczuk, J.; Vaysse, N.; Susini, C.; Buscail, L. sst2 somatostatin receptor mediates cell cycle arrest and induction of p27(Kip1). Evidence for the role of SHP-1. J. Biol. Chem. 1999, 274, 15186-15193. [CrossRef]

39. Ruscica, M.; Magni, P.; Steffani, L.; Gatto, F.; Albertelli, M.; Rametta, R.; Valenti, L.; Ameri, P.; Magnaghi, V.; Culler, M.D.; et al. Characterization and sub-cellular localization of SS1R, SS2R, and SS5R in human late-stage prostate cancer cells: Effect of mono- and bi-specific somatostatin analogs on cell growth. Mol. Cell. Endocrinol. 2014, 382, 860-870. [CrossRef]

40. Theodoropoulou, M.; Zhang, J.; Laupheimer, S.; Paez-Pereda, M.; Erneux, C.; Florio, T.; Pagotto, U.; Stalla, G.K. Octreotide, a somatostatin analogue, mediates its antiproliferative action in pituitary tumor cells by altering phosphatidylinositol 3-kinase signaling and inducing Zac1 expression. Cancer Res. 2006, 66, 1576-1582. [CrossRef]

41. Barbieri, F.; Pattarozzi, A.; Gatti, M.; Porcile, C.; Bajetto, A.; Ferrari, A.; Culler, M.D.; Florio, T. Somatostatin receptors 1,2, and 5 cooperate in the somatostatin inhibition of C6 glioma cell proliferation in vitro via a phosphotyrosine phosphatase-eta-dependent inhibition of extracellularly regulated kinase-1/2. Endocrinology 2008, 149, 4736-4746. [CrossRef]

42. Cordelier, P.; Esteve, J.P.; Bousquet, C.; Delesque, N.; O’Carroll, A.M.; Schally, A.V.; Vaysse, N.; Susini, C.; Buscail, L. Characterization of the antiproliferative signal mediated by the somatostatin receptor subtype sst5. Proc. Natl. Acad. Sci. USA 1997, 94, 9343-9348. [CrossRef] 
43. Hubina, E.; Nanzer, A.M.; Hanson, M.R.; Ciccarelli, E.; Losa, M.; Gaia, D.; Papotti, M.; Terreni, M.R.; Khalaf, S.; Jordan, S.; et al. Somatostatin analogues stimulate p27 expression and inhibit the MAP kinase pathway in pituitary tumours. Eur. J. Endocrinol. 2006, 155, 371-379. [CrossRef]

44. Lahlou, H.; Saint-Laurent, N.; Esteve, J.P.; Eychene, A.; Pradayrol, L.; Pyronnet, S.; Susini, C. sst2 Somatostatin receptor inhibits cell proliferation through Ras-, Rap1-, and B-Raf-dependent ERK2 activation. J. Biol. Chem. 2003, 278, 39356-39371. [CrossRef]

45. Pola, S.; Cattaneo, M.G.; Vicentini, L.M. Anti-migratory and anti-invasive effect of somatostatin in human neuroblastoma cells: Involvement of Rac and MAP kinase activity. J. Biol. Chem. 2003, 278, 40601-40606. [CrossRef]

46. Pan, M.G.; Florio, T.; Stork, P.J. G protein activation of a hormone-stimulated phosphatase in human tumor cells. Science 1992, 256, 1215-1217. [CrossRef]

47. Florio, T. Somatostatin/somatostatin receptor signalling: Phosphotyrosine phosphatases. Mol. Cell. Endocrinol. 2008, 286, 40-48. [CrossRef]

48. Florio, T.; Arena, S.; Thellung, S.; Iuliano, R.; Corsaro, A.; Massa, A.; Pattarozzi, A.; Bajetto, A.; Trapasso, F.; Fusco, A.; et al. The activation of the phosphotyrosine phosphatase eta (r-PTP eta) is responsible for the somatostatin inhibition of PC Cl3 thyroid cell proliferation. Mol. Endocrinol. 2001, 15, 1838-1852.

49. Florio, T.; Thellung, S.; Arena, S.; Corsaro, A.; Spaziante, R.; Gussoni, G.; Acuto, G.; Giusti, M.; Giordano, G.; Schettini, G. Somatostatin and its analog lanreotide inhibit the proliferation of dispersed human non-functioning pituitary adenoma cells in vitro. Eur. J. Endocrinol. 1999, 141, 396-408. [CrossRef]

50. Florio, T.; Thellung, S.; Corsaro, A.; Bocca, L.; Arena, S.; Pattarozzi, A.; Villa, V.; Massa, A.; Diana, F.; Schettini, D.; et al. Characterization of the intracellular mechanisms mediating somatostatin and lanreotide inhibition of DNA synthesis and growth hormone release from dispersed human GH-secreting pituitary adenoma cells in vitro. Clin. Endocrinol. 2003, 59, 115-128. [CrossRef]

51. Cerovac, V.; Monteserin-Garcia, J.; Rubinfeld, H.; Buchfelder, M.; Losa, M.; Florio, T.; Paez-Pereda, M.; Stalla, G.K.; Theodoropoulou, M. The somatostatin analogue octreotide confers sensitivity to rapamycin treatment on pituitary tumor cells. Cancer Res. 2010, 70, 666-674. [CrossRef]

52. Florio, T.; Rim, C.; Hershberger, R.E.; Loda, M.; Stork, P.J. The somatostatin receptor SSTR1 is coupled to phosphotyrosine phosphatase activity in CHO-K1 cells. Mol. Endocrinol. 1994, 8, 1289-1297.

53. Florio, T.; Thellung, S.; Arena, S.; Corsaro, A.; Bajetto, A.; Schettini, G.; Stork, P.J. Somatostatin receptor 1 (SSTR1)-mediated inhibition of cell proliferation correlates with the activation of the MAP kinase cascade: Role of the phosphotyrosine phosphatase SHP-2. J. Physiol. Paris 2000, 94, 239-250. [CrossRef]

54. Lopez, F.; Esteve, J.P.; Buscail, L.; Delesque, N.; Saint-Laurent, N.; Theveniau, M.; Nahmias, C.; Vaysse, N.; Susini, C. The tyrosine phosphatase SHP-1 associates with the sst2 somatostatin receptor and is an essential component of sst2-mediated inhibitory growth signaling. J. Biol. Chem. 1997, 272, 24448-24454. [CrossRef]

55. Reardon, D.B.; Dent, P.; Wood, S.L.; Kong, T.; Sturgill, T.W. Activation in vitro of somatostatin receptor subtypes 2, 3, or 4 stimulates protein tyrosine phosphatase activity in membranes from transfected Ras-transformed NIH 3T3 cells: Coexpression with catalytically inactive SHP-2 blocks responsiveness. Mol. Endocrinol. 1997, 11, 1062-1069. [CrossRef]

56. Yamamoto, J.; Ohnuma, K.; Hatano, R.; Okamoto, T.; Komiya, E.; Yamazaki, H.; Iwata, S.; Dang, N.H.; Aoe, K.; Kishimoto, T.; et al. Regulation of somatostatin receptor 4-mediated cytostatic effects by CD26 in malignant pleural mesothelioma. Br. J. Cancer 2014, 110, 2232-2245. [CrossRef]

57. Barbieri, F.; Pattarozzi, A.; Gatti, M.; Aiello, C.; Quintero, A.; Lunardi, G.; Bajetto, A.; Ferrari, A.; Culler, M.D.; Florio, T. Differential efficacy of SSTR1, -2 , and -5 agonists in the inhibition of $\mathrm{C} 6$ glioma growth in nude mice. Am. J. Physiol. Endocrinol. Metab. 2009, 297, E1078-E1088. [CrossRef]

58. Cattaneo, M.G.; Taylor, J.E.; Culler, M.D.; Nisoli, E.; Vicentini, L.M. Selective stimulation of somatostatin receptor subtypes: Differential effects on Ras/MAP kinase pathway and cell proliferation in human neuroblastoma cells. FEBS Lett. 2000, 481, 271-276. [CrossRef]

59. Akbar, M.; Okajima, F.; Tomura, H.; Majid, M.A.; Yamada, Y.; Seino, S.; Kondo, Y. Phospholipase C activation and $\mathrm{Ca}^{2+}$ mobilization by cloned human somatostatin receptor subtypes $1-5$, in transfected COS-7 cells. FEBS Lett. 1994, 348, 192-196. [CrossRef] 
60. Kim, J.K.; Kwon, O.; Kim, J.; Kim, E.K.; Park, H.K.; Lee, J.E.; Kim, K.L.; Choi, J.W.; Lim, S.; Seok, H.; et al. PDZ domain-containing 1 (PDZK1) protein regulates phospholipase C-beta3 (PLC-beta3)-specific activation of somatostatin by forming a ternary complex with PLC-beta3 and somatostatin receptors. J. Biol. Chem. 2012, 287, 21012-21024. [CrossRef]

61. Alderton, F.; Humphrey, P.P.; Sellers, L.A. High-intensity p38 kinase activity is critical for p21 (cip1) induction and the antiproliferative function of G (i) protein-coupled receptors. Mol. Pharmacol. 2001, 59, 1119-1128. [CrossRef]

62. War, S.A.; Kim, B.; Kumar, U. Human somatostatin receptor-3 distinctively induces apoptosis in MCF-7 and cell cycle arrest in MDA-MB-231 breast cancer cells. Mol. Cell. Endocrinol. 2015, 413, 129-144. [CrossRef]

63. Sharma, K.; Patel, Y.C.; Srikant, C.B. Subtype-selective induction of wild-type p53 and apoptosis, but not cell cycle arrest, by human somatostatin receptor 3. Mol. Endocrinol. 1996, 10, 1688-1696.

64. Guillermet, J.; Saint-Laurent, N.; Rochaix, P.; Cuvillier, O.; Levade, T.; Schally, A.V.; Pradayrol, L.; Buscail, L.; Susini, C.; Bousquet, C. Somatostatin receptor subtype 2 sensitizes human pancreatic cancer cells to death ligand-induced apoptosis. Proc. Natl. Acad. Sci. USA 2003, 100, 155-160. [CrossRef]

65. Scoazec, J.Y. Angiogenesis in neuroendocrine tumors: Therapeutic applications. Neuroendocrinology 2013, 97, 45-56. [CrossRef]

66. Albini, A.; Florio, T.; Giunciuglio, D.; Masiello, L.; Carlone, S.; Corsaro, A.; Thellung, S.; Cai, T.; Noonan, D.M.; Schettini, G. Somatostatin controls Kaposi's sarcoma tumor growth through inhibition of angiogenesis. FASEB J.: Off. Publ. Fed. Am. Soc. Exp. Biol. 1999, 13, 647-655. [CrossRef]

67. Bocci, G.; Culler, M.D.; Fioravanti, A.; Orlandi, P.; Fasciani, A.; Colucci, R.; Taylor, J.E.; Sadat, D.; Danesi, R.; Del Tacca, M. In vitro antiangiogenic activity of selective somatostatin subtype-1 receptor agonists. Eur. J. Clin. Investig. 2007, 37, 700-708. [CrossRef]

68. Kumar, M.; Liu, Z.R.; Thapa, L.; Chang, Q.; Wang, D.Y.; Qin, R.Y. Antiangiogenic effect of somatostatin receptor subtype 2 on pancreatic cancer cell line: Inhibition of vascular endothelial growth factor and matrix metalloproteinase-2 expression in vitro. World J. Gastroenterol 2004, 10, 393-399. [CrossRef]

69. Florio, T.; Morini, M.; Villa, V.; Arena, S.; Corsaro, A.; Thellung, S.; Culler, M.D.; Pfeffer, U.; Noonan, D.M.; Schettini, G.; et al. Somatostatin inhibits tumor angiogenesis and growth via somatostatin receptor-3-mediated regulation of endothelial nitric oxide synthase and mitogen-activated protein kinase activities. Endocrinology 2003, 144, 1574-1584. [CrossRef]

70. Patel, P.C.; Barrie, R.; Hill, N.; Landeck, S.; Kurozawa, D.; Woltering, E.A. Postreceptor signal transduction mechanisms involved in octreotide-induced inhibition of angiogenesis. Surgery 1994, 116, 1148-1152.

71. Arena, S.; Pattarozzi, A.; Corsaro, A.; Schettini, G.; Florio, T. Somatostatin receptor subtype-dependent regulation of nitric oxide release: Involvement of different intracellular pathways. Mol. Endocrinol. 2005, 19, 255-267. [CrossRef]

72. Cordelier, P.; Esteve, J.P.; Najib, S.; Moroder, L.; Vaysse, N.; Pradayrol, L.; Susini, C.; Buscail, L. Regulation of neuronal nitric-oxide synthase activity by somatostatin analogs following SST5 somatostatin receptor activation. J. Biol. Chem. 2006, 281, 19156-19171. [CrossRef]

73. Cordoba-Chacon, J.; Gahete, M.D.; Duran-Prado, M.; Luque, R.M.; Castano, J.P. Truncated somatostatin receptors as new players in somatostatin-cortistatin pathophysiology. Ann. New York Acad. Sci. 2011, 1220, 6-15. [CrossRef]

74. Gahete, M.D.; Rincon-Fernandez, D.; Duran-Prado, M.; Hergueta-Redondo, M.; Ibanez-Costa, A.; Rojo-Sebastian, A.; Gracia-Navarro, F.; Culler, M.D.; Casanovas, O.; Moreno-Bueno, G.; et al. The truncated somatostatin receptor sst5TMD4 stimulates the angiogenic process and is associated to lymphatic metastasis and disease-free survival in breast cancer patients. Oncotarget 2016, 7, 60110-60122. [CrossRef]

75. Lin, C.Y.; Varma, M.G.; Joubel, A.; Madabushi, S.; Lichtarge, O.; Barber, D.L. Conserved motifs in somatostatin, D2-dopamine, and alpha 2B-adrenergic receptors for inhibiting the Na-H exchanger, NHE1. J. Biol. Chem. 2003, 278, 15128-15135. [CrossRef]

76. Buchan, A.M.; Lin, C.Y.; Choi, J.; Barber, D.L. Somatostatin, acting at receptor subtype 1, inhibits Rho activity, the assembly of actin stress fibers, and cell migration. J. Biol. Chem. 2002, 277, 28431-28438. [CrossRef]

77. Bulenger, S.; Marullo, S.; Bouvier, M. Emerging role of homo- and heterodimerization in G-protein-coupled receptor biosynthesis and maturation. Trends Pharmacol. Sci. 2005, 26, 131-137. [CrossRef]

78. Milligan, G. G protein-coupled receptor dimerisation: Molecular basis and relevance to function. Biochim. Et Biophys. Acta 2007, 1768, 825-835. [CrossRef] 
79. Grant, M.; Collier, B.; Kumar, U. Agonist-dependent dissociation of human somatostatin receptor 2 dimers: A role in receptor trafficking. J. Biol. Chem. 2004, 279, 36179-36183. [CrossRef]

80. Pfeiffer, M.; Koch, T.; Schroder, H.; Klutzny, M.; Kirscht, S.; Kreienkamp, H.J.; Hollt, V.; Schulz, S. Homoand heterodimerization of somatostatin receptor subtypes. Inactivation of sst (3) receptor function by heterodimerization with sst (2A). J. Biol. Chem. 2001, 276, 14027-14036. [CrossRef]

81. Grant, M.; Patel, R.C.; Kumar, U. The role of subtype-specific ligand binding and the C-tail domain in dimer formation of human somatostatin receptors. J. Biol. Chem. 2004, 279, 38636-38643. [CrossRef]

82. Patel, R.C.; Kumar, U.; Lamb, D.C.; Eid, J.S.; Rocheville, M.; Grant, M.; Rani, A.; Hazlett, T.; Patel, S.C.; Gratton, E.; et al. Ligand binding to somatostatin receptors induces receptor-specific oligomer formation in live cells. Proc. Natl. Acad. Sci. USA. 2002, 99, 3294-3299. [CrossRef]

83. Rocheville, M.; Lange, D.C.; Kumar, U.; Sasi, R.; Patel, R.C.; Patel, Y.C. Subtypes of the somatostatin receptor assemble as functional homo- and heterodimers. J. Biol. Chem. 2000, 275, 7862-7869. [CrossRef]

84. Ruscica, M.; Arvigo, M.; Gatto, F.; Dozio, E.; Feltrin, D.; Culler, M.D.; Minuto, F.; Motta, M.; Ferone, D.; Magni, P. Regulation of prostate cancer cell proliferation by somatostatin receptor activation. Mol. Cell. Endocrinol. 2010, 315, 254-262. [CrossRef]

85. Zou, Y.; Tan, H.; Zhao, Y.; Zhou, Y.; Cao, L. Expression and selective activation of somatostatin receptor subtypes induces cell cycle arrest in cancer cells. Oncol. Lett. 2019, 17, 1723-1731. [CrossRef]

86. Grant, M.; Alturaihi, H.; Jaquet, P.; Collier, B.; Kumar, U. Cell growth inhibition and functioning of human somatostatin receptor type 2 are modulated by receptor heterodimerization. Mol. Endocrinol. 2008, 22, 2278-2292. [CrossRef]

87. Pfeiffer, M.; Koch, T.; Schroder, H.; Laugsch, M.; Hollt, V.; Schulz, S. Heterodimerization of somatostatin and opioid receptors cross-modulates phosphorylation, internalization, and desensitization. J. Biol. Chem. 2002, 277, 19762-19772. [CrossRef]

88. Rocheville, M.; Lange, D.C.; Kumar, U.; Patel, S.C.; Patel, R.C.; Patel, Y.C. Receptors for dopamine and somatostatin: Formation of hetero-oligomers with enhanced functional activity. Science 2000, 288, 154-157. [CrossRef]

89. Baragli, A.; Alturaihi, H.; Watt, H.L.; Abdallah, A.; Kumar, U. Heterooligomerization of human dopamine receptor 2 and somatostatin receptor 2 Co-immunoprecipitation and fluorescence resonance energy transfer analysis. Cell. Signal. 2007, 19, 2304-2316. [CrossRef]

90. Somvanshi, R.K.; War, S.A.; Chaudhari, N.; Qiu, X.; Kumar, U. Receptor specific crosstalk and modulation of signaling upon heterodimerization between beta1-adrenergic receptor and somatostatin receptor-5. Cell. Signal. 2011, 23, 794-811. [CrossRef]

91. Taylor, J.E.; Bogden, A.E.; Moreau, J.P.; Coy, D.H. In vitro and in vivo inhibition of human small cell lung carcinoma (NCI-H69) growth by a somatostatin analogue. Biochem. Biophys. Res. Commun. 1988, 153, 81-86. [CrossRef]

92. Kuhn, J.M.; Basin, C.; Mollard, M.; de Rouge, B.; Baudoin, C.; Obach, R.; Tolis, G. Pharmacokinetic study and effects on growth hormone secretion in healthy volunteers of the new somatostatin analogue BIM 23014. Eur. J. Clin. Pharm. 1993, 45, 73-77. [CrossRef]

93. Ben-Shlomo, A.; Melmed, S. Somatostatin agonists for treatment of acromegaly. Mol. Cell. Endocrinol. 2008, 286, 192-198. [CrossRef]

94. Gadelha, M.R.; Wildemberg, L.E.; Bronstein, M.D.; Gatto, F.; Ferone, D. Somatostatin receptor ligands in the treatment of acromegaly. Pituitary 2017, 20, 100-108. [CrossRef]

95. Oberg, K.; Lamberts, S.W. Somatostatin analogues in acromegaly and gastroenteropancreatic neuroendocrine tumours: Past, present and future. Endocr. -Relat. Cancer 2016, 23, R551-R566. [CrossRef]

96. Lancranjan, I.; Bruns, C.; Grass, P.; Jaquet, P.; Jervell, J.; Kendall-Taylor, P.; Lamberts, S.W.; Marbach, P.; Orskov, H.; Pagani, G.; et al. Sandostatin LAR: A promising therapeutic tool in the management of acromegalic patients. Metabolism 1996, 45, 67-71. [CrossRef]

97. Pouget, E.; Fay, N.; Dujardin, E.; Jamin, N.; Berthault, P.; Perrin, L.; Pandit, A.; Rose, T.; Valery, C.; Thomas, D.; et al. Elucidation of the self-assembly pathway of lanreotide octapeptide into beta-sheet nanotubes: Role of two stable intermediates. J. Am. Chem. Soc. 2010, 132, 4230-4241. [CrossRef]

98. Caron, P.; Beckers, A.; Cullen, D.R.; Goth, M.I.; Gutt, B.; Laurberg, P.; Pico, A.M.; Valimaki, M.; Zgliczynski, W. Efficacy of the new long-acting formulation of lanreotide (lanreotide Autogel) in the management of acromegaly. J. Clin. Endocrinol. Metab. 2002, 87, 99-104. [CrossRef] 
99. Astruc, B.; Marbach, P.; Bouterfa, H.; Denot, C.; Safari, M.; Vitaliti, A.; Sheppard, M. Long-acting octreotide and prolonged-release lanreotide formulations have different pharmacokinetic profiles. J. Clin. Pharmacol. 2005, 45, 836-844. [CrossRef]

100. Bruns, C.; Lewis, I.; Briner, U.; Meno-Tetang, G.; Weckbecker, G. SOM230: A novel somatostatin peptidomimetic with broad somatotropin release inhibiting factor (SRIF) receptor binding and a unique antisecretory profile. Eur. J. Endocrinol. 2002, 146, 707-716. [CrossRef]

101. Reubi, J.C.; Eisenwiener, K.P.; Rink, H.; Waser, B.; Macke, H.R. A new peptidic somatostatin agonist with high affinity to all five somatostatin receptors. Eur. J. Pharm. 2002, 456, 45-49. [CrossRef]

102. Petersenn, S.; Hu, K.; Maldonado, M.; Zhang, Y.; Lasher, J.; Bouillaud, E.; Wang, Y.; Mann, K.; Unger, N. Tolerability and dose proportional pharmacokinetics of pasireotide administered as a single dose or two divided doses in healthy male volunteers: A single-center, open-label, ascending-dose study. Clin. Ther. 2012, 34, 677-688. [CrossRef]

103. Dietrich, H.; Hu, K.; Ruffin, M.; Song, D.; Bouillaud, E.; Wang, Y.; Hasskarl, J. Safety, tolerability, and pharmacokinetics of a single dose of pasireotide long-acting release in healthy volunteers: A single-center Phase I study. Eur. J. Endocrinol. 2012, 166, 821-828. [CrossRef]

104. Lesche, S.; Lehmann, D.; Nagel, F.; Schmid, H.A.; Schulz, S. Differential effects of octreotide and pasireotide on somatostatin receptor internalization and trafficking in vitro. J. Clin. Endocrinol. Metab. 2009, 94, 654-661. [CrossRef]

105. Hofland, L.J.; van der Hoek, J.; Feelders, R.; van Aken, M.O.; van Koetsveld, P.M.; Waaijers, M.; Sprij-Mooij, D.; Bruns, C.; Weckbecker, G.; de Herder, W.W.; et al. The multi-ligand somatostatin analogue SOM230 inhibits ACTH secretion by cultured human corticotroph adenomas via somatostatin receptor type 5. Eur. J. Endocrinol. 2005, 152, 645-654. [CrossRef]

106. Gatto, F.; Arvigo, M.; Amaru, J.; Campana, C.; Cocchiara, F.; Graziani, G.; Bruzzone, E.; Giusti, M.; Boschetti, M.; Ferone, D. Cell specific interaction of pasireotide: Review of preclinical studies in somatotroph and corticotroph pituitary cells. Pituitary 2019, 22, 89-99. [CrossRef]

107. Lahlou, H.; Guillermet, J.; Hortala, M.; Vernejoul, F.; Pyronnet, S.; Bousquet, C.; Susini, C. Molecular signaling of somatostatin receptors. Ann. New York Acad. Sci. 2004, 1014, 121-131. [CrossRef]

108. Schonbrunn, A. Selective agonism in somatostatin receptor signaling and regulation. Mol. Cell. Endocrinol. 2008, 286, 35-39. [CrossRef]

109. Kao, Y.J.; Ghosh, M.; Schonbrunn, A. Ligand-dependent mechanisms of sst2A receptor trafficking: Role of site-specific phosphorylation and receptor activation in the actions of biased somatostatin agonists. Mol. Endocrinol. 2011, 25, 1040-1054. [CrossRef]

110. Poll, F.; Lehmann, D.; Illing, S.; Ginj, M.; Jacobs, S.; Lupp, A.; Stumm, R.; Schulz, S. Pasireotide and octreotide stimulate distinct patterns of sst2A somatostatin receptor phosphorylation. Mol. Endocrinol. 2010, 24, 436-446. [CrossRef]

111. Cescato, R.; Loesch, K.A.; Waser, B.; Macke, H.R.; Rivier, J.E.; Reubi, J.C.; Schonbrunn, A. Agonist-biased signaling at the sst2A receptor: The multi-somatostatin analogs KE108 and SOM230 activate and antagonize distinct signaling pathways. Mol. Endocrinol. 2010, 24, 240-249. [CrossRef] [PubMed]

112. Nagel, F.; Doll, C.; Poll, F.; Kliewer, A.; Schroder, H.; Schulz, S. Structural determinants of agonist-selective signaling at the sst (2A) somatostatin receptor. Mol. Endocrinol. 2011, 25, 859-866. [CrossRef] [PubMed]

113. Gurevich, V.V.; Gurevich, E.V. The structural basis of arrestin-mediated regulation of G-protein-coupled receptors. Pharm. Ther. 2006, 110, 465-502. [CrossRef] [PubMed]

114. Oakley, R.H.; Revollo, J.; Cidlowski, J.A. Glucocorticoids regulate arrestin gene expression and redirect the signaling profile of G protein-coupled receptors. Proc. Natl. Acad. Sci. USA 2012, 109, 17591-17596. [CrossRef] [PubMed]

115. Liu, Q.; Bee, M.S.; Schonbrunn, A. Site specificity of agonist and second messenger-activated kinases for somatostatin receptor subtype 2A (Sst2A) phosphorylation. Mol. Pharmacol. 2009, 76, 68-80. [CrossRef] [PubMed]

116. Lehmann, A.; Kliewer, A.; Schutz, D.; Nagel, F.; Stumm, R.; Schulz, S. Carboxyl-terminal multi-site phosphorylation regulates internalization and desensitization of the human sst2 somatostatin receptor. Mol. Cell. Endocrinol. 2014, 387, 44-51. [CrossRef] [PubMed] 
117. Mohamed, A.; Blanchard, M.P.; Albertelli, M.; Barbieri, F.; Brue, T.; Niccoli, P.; Delpero, J.R.; Monges, G.; Garcia, S.; Ferone, D.; et al. Pasireotide and octreotide antiproliferative effects and sst2 trafficking in human pancreatic neuroendocrine tumor cultures. Endocr. Relat. Cancer 2014, 21, 691-704. [CrossRef]

118. Gatto, F.; Biermasz, N.R.; Feelders, R.A.; Kros, J.M.; Dogan, F.; van der Lely, A.J.; Neggers, S.J.; Lamberts, S.W.; Pereira, A.M.; Ferone, D.; et al. Low beta-arrestin expression correlates with the responsiveness to long-term somatostatin analog treatment in acromegaly. Eur. J. Endocrinol. 2016, 174, 651-662. [CrossRef]

119. Gatto, F.; Feelders, R.; van der Pas, R.; Kros, J.M.; Dogan, F.; van Koetsveld, P.M.; van der Lelij, A.J.; Neggers, S.J.; Minuto, F.; de Herder, W.; et al. beta-Arrestin 1 and 2 and G protein-coupled receptor kinase 2 expression in pituitary adenomas: Role in the regulation of response to somatostatin analogue treatment in patients with acromegaly. Endocrinology 2013, 154, 4715-4725. [CrossRef]

120. Melmed, S. Medical progress: Acromegaly. New Engl. J. Med. 2006, 355, 2558-2573. [CrossRef]

121. Katznelson, L.; Laws, E.R., Jr.; Melmed, S.; Molitch, M.E.; Murad, M.H.; Utz, A.; Wass, J.A.; Endocrine, S. Acromegaly: An endocrine society clinical practice guideline. J. Clin. Endocrinol. Metab. 2014, 99, 3933-3951. [CrossRef]

122. Jane, J.A., Jr.; Starke, R.M.; Elzoghby, M.A.; Reames, D.L.; Payne, S.C.; Thorner, M.O.; Marshall, J.C.; Laws, E.R., Jr.; Vance, M.L. Endoscopic transsphenoidal surgery for acromegaly: Remission using modern criteria, complications, and predictors of outcome. J. Clin. Endocrinol. Metab. 2011, 96, 2732-2740. [CrossRef]

123. Nomikos, P.; Buchfelder, M.; Fahlbusch, R. The outcome of surgery in 668 patients with acromegaly using current criteria of biochemical 'cure'. Eur. J. Endocrinol. 2005, 152, 379-387. [CrossRef]

124. Giustina, A.; Chanson, P.; Kleinberg, D.; Bronstein, M.D.; Clemmons, D.R.; Klibanski, A.; van der Lely, A.J.; Strasburger, C.J.; Lamberts, S.W.; Ho, K.K.; et al. Expert consensus document: A consensus on the medical treatment of acromegaly. Nat. Rev. Endocrinol. 2014, 10, 243-248. [CrossRef]

125. Colao, A.; Auriemma, R.S.; Pivonello, R.; Kasuki, L.; Gadelha, M.R. Interpreting biochemical control response rates with first-generation somatostatin analogues in acromegaly. Pituitary 2016, 19, 235-247. [CrossRef]

126. Murray, R.D.; Kim, K.; Ren, S.G.; Lewis, I.; Weckbecker, G.; Bruns, C.; Melmed, S. The novel somatostatin ligand (SOM230) regulates human and rat anterior pituitary hormone secretion. J. Clin. Endocrinol. Metab. 2004, 89, 3027-3032. [CrossRef]

127. Hofland, L.J.; van der Hoek, J.; van Koetsveld, P.M.; de Herder, W.W.; Waaijers, M.; Sprij-Mooij, D.; Bruns, C.; Weckbecker, G.; Feelders, R.; van der Lely, A.J.; et al. The novel somatostatin analog SOM230 is a potent inhibitor of hormone release by growth hormone- and prolactin-secreting pituitary adenomas in vitro. J. Clin. Endocrinol. Metab. 2004, 89, 1577-1585. [CrossRef]

128. Ibanez-Costa, A.; Rivero-Cortes, E.; Vazquez-Borrego, M.C.; Gahete, M.D.; Jimenez-Reina, L.; Venegas-Moreno, E.; de la Riva, A.; Arraez, M.A.; Gonzalez-Molero, I.; Schmid, H.A.; et al. Octreotide and pasireotide (dis)similarly inhibit pituitary tumor cells in vitro. J. Endocrinol. 2016, 231, 135-145. [CrossRef]

129. Gatto, F.; Feelders, R.A.; Franck, S.E.; van Koetsveld, P.M.; Dogan, F.; Kros, J.M.; Neggers, S.; van der Lely, A.J.; Lamberts, S.W.J.; Ferone, D.; et al. In Vitro Head-to-Head Comparison between Octreotide and Pasireotide in GH-Secreting Pituitary Adenomas. J. Clin. Endocrinol. Metab. 2017, 102, 2009-2018. [CrossRef]

130. Colao, A.; Bronstein, M.D.; Freda, P.; Gu, F.; Shen, C.C.; Gadelha, M.; Fleseriu, M.; van der Lely, A.J.; Farrall, A.J.; Hermosillo Resendiz, K.; et al. Pasireotide versus octreotide in acromegaly: A head-to-head superiority study. J. Clin. Endocrinol. Metab. 2014, 99, 791-799. [CrossRef]

131. Gadelha, M.R.; Bronstein, M.D.; Brue, T.; Coculescu, M.; Fleseriu, M.; Guitelman, M.; Pronin, V.; Raverot, G.; Shimon, I.; Lievre, K.K.; et al. Pasireotide versus continued treatment with octreotide or lanreotide in patients with inadequately controlled acromegaly (PAOLA): A randomised, phase 3 trial. Lancet. Diabetes Endocrinol. 2014, 2, 875-884. [CrossRef]

132. Cuny, T.; Barlier, A.; Feelders, R.; Weryha, G.; Hofland, L.J.; Ferone, D.; Gatto, F. Medical therapies in pituitary adenomas: Current rationale for the use and future perspectives. Ann. D'endocrinologie 2015, 76, 43-58. [CrossRef]

133. Ferone, D.; Gatto, F.; Arvigo, M.; Resmini, E.; Boschetti, M.; Teti, C.; Esposito, D.; Minuto, F. The clinicalmolecular interface of somatostatin, dopamine and their receptors in pituitary pathophysiology. J. Mol. Endocrinol. 2009, 42, 361-370. [CrossRef]

134. Stalla, G.K.; Brockmeier, S.J.; Renner, U.; Newton, C.; Buchfelder, M.; Stalla, J.; Muller, O.A. Octreotide exerts different effects in vivo and in vitro in Cushing's disease. Eur. J. Endocrinol. 1994, 130, 125-131. [CrossRef] 
135. van der Pas, R.; Feelders, R.A.; Gatto, F.; de Bruin, C.; Pereira, A.M.; van Koetsveld, P.M.; Sprij-Mooij, D.M.; Waaijers, A.M.; Dogan, F.; Schulz, S.; et al. Preoperative normalization of cortisol levels in Cushing's disease after medical treatment: Consequences for somatostatin and dopamine receptor subtype expression and in vitro response to somatostatin analogs and dopamine agonists. J. Clin. Endocrinol. Metab. 2013, 98, E1880-E1890. [CrossRef]

136. Gatto, F.; Hofland, L.J. The role of somatostatin and dopamine D2 receptors in endocrine tumors. Endocr. Relat. Cancer 2011, 18, R233-R251. [CrossRef]

137. van der Hoek, J.; Waaijers, M.; van Koetsveld, P.M.; Sprij-Mooij, D.; Feelders, R.A.; Schmid, H.A.; Schoeffter, P.; Hoyer, D.; Cervia, D.; Taylor, J.E.; et al. Distinct functional properties of native somatostatin receptor subtype 5 compared with subtype 2 in the regulation of ACTH release by corticotroph tumor cells. Am. J. Physiol. Endocrinol. Metab. 2005, 289, E278-E287. [CrossRef]

138. de Bruin, C.; Feelders, R.A.; Waaijers, A.M.; van Koetsveld, P.M.; Sprij-Mooij, D.M.; Lamberts, S.W.; Hofland, L.J. Differential regulation of human dopamine D2 and somatostatin receptor subtype expression by glucocorticoids in vitro. J. Mol. Endocrinol. 2009, 42, 47-56. [CrossRef]

139. Ben-Shlomo, A.; Schmid, H.; Wawrowsky, K.; Pichurin, O.; Hubina, E.; Chesnokova, V.; Liu, N.A.; Culler, M.; Melmed, S. Differential ligand-mediated pituitary somatostatin receptor subtype signaling: Implications for corticotroph tumor therapy. J. Clin. Endocrinol. Metab. 2009, 94, 4342-4350. [CrossRef]

140. Lamberts, S.W.; de Lange, S.A.; Stefanko, S.Z. Adrenocorticotropin-secreting pituitary adenomas originate from the anterior or the intermediate lobe in Cushing's disease: Differences in the regulation of hormone secretion. J. Clin. Endocrinol. Metab. 1982, 54, 286-291. [CrossRef]

141. Pivonello, R.; De Leo, M.; Cozzolino, A.; Colao, A. The Treatment of Cushing's Disease. Endocr. Rev. 2015, 36, 385-486. [CrossRef]

142. Boscaro, M.; Ludlam, W.H.; Atkinson, B.; Glusman, J.E.; Petersenn, S.; Reincke, M.; Snyder, P.; Tabarin, A.; Biller, B.M.; Findling, J.; et al. Treatment of pituitary-dependent Cushing's disease with the multireceptor ligand somatostatin analog pasireotide (SOM230): A multicenter, phase II trial. J. Clin. Endocrinol. Metab. 2009, 94, 115-122. [CrossRef]

143. Lacroix, A.; Gu, F.; Gallardo, W.; Pivonello, R.; Yu, Y.; Witek, P.; Boscaro, M.; Salvatori, R.; Yamada, M.; Tauchmanova, L.; et al. Efficacy and safety of once-monthly pasireotide in Cushing's disease: A 12 month clinical trial. Lancet. Diabetes Endocrinol. 2018, 6, 17-26. [CrossRef]

144. Pivonello, R.; Arnaldi, G.; Scaroni, C.; Giordano, C.; Cannavo, S.; Iacuaniello, D.; Trementino, L.; Zilio, M.; Guarnotta, V.; Albani, A.; et al. The medical treatment with pasireotide in Cushing's disease: An Italian multicentre experience based on "real-world evidence". Endocrine 2019, 64, 657-672. [CrossRef]

145. Gatto, F.; Barbieri, F.; Gatti, M.; Wurth, R.; Schulz, S.; Ravetti, J.L.; Zona, G.; Culler, M.D.; Saveanu, A.; Giusti, M.; et al. Balance between somatostatin and D2 receptor expression drives TSH-secreting adenoma response to somatostatin analogues and dopastatins. Clin. Endocrinol. 2012, 76, 407-414. [CrossRef]

146. Oronsky, B.; Ma, P.C.; Morgensztern, D.; Carter, C.A. Nothing but NET: A Review of Neuroendocrine Tumors and Carcinomas. Neoplasia 2017, 19, 991-1002. [CrossRef]

147. Rindi, G.; Klersy, C.; Albarello, L.; Baudin, E.; Bianchi, A.; Buchler, M.W.; Caplin, M.; Couvelard, A.; Cros, J.; de Herder, W.W.; et al. Competitive Testing of the WHO 2010 versus the WHO 2017 Grading of Pancreatic Neuroendocrine Neoplasms: Data from a Large International Cohort Study. Neuroendocrinology 2018, 107, 375-386. [CrossRef]

148. Dasari, A.; Shen, C.; Halperin, D.; Zhao, B.; Zhou, S.; Xu, Y.; Shih, T.; Yao, J.C. Trends in the Incidence, Prevalence, and Survival Outcomes in Patients With Neuroendocrine Tumors in the United States. JAMA Oncol. 2017, 3, 1335-1342. [CrossRef]

149. Kloppel, G. Neuroendocrine Neoplasms: Dichotomy, Origin and Classifications. Visc. Med. 2017, 33, 324-330. [CrossRef]

150. Oberg, K.; Couvelard, A.; Delle Fave, G.; Gross, D.; Grossman, A.; Jensen, R.T.; Pape, U.F.; Perren, A.; Rindi, G.; Ruszniewski, P.; et al. Antibes Consensus Conference, p., ENETS Consensus Guidelines for Standard of Care in Neuroendocrine Tumours: Biochemical Markers. Neuroendocrinology 2017, 105, $201-211$. [CrossRef]

151. Oberg, K. Neuroendocrine tumors: Recent progress in diagnosis and treatment. Endocr. Relat. Cancer 2011, 18, E3. [CrossRef] 
152. Kloppel, G.; Rindi, G.; Perren, A.; Komminoth, P.; Klimstra, D.S. The ENETS and AJCC/UICC TNM classifications of the neuroendocrine tumors of the gastrointestinal tract and the pancreas: A statement. Virchows Arch. Int. J. Pathol. 2010, 456, 595-597. [CrossRef]

153. Mai, R.; Kaemmerer, D.; Trager, T.; Neubauer, E.; Sanger, J.; Baum, R.P.; Schulz, S.; Lupp, A. Different somatostatin and CXCR4 chemokine receptor expression in gastroenteropancreatic neuroendocrine neoplasms depending on their origin. Sci. Rep. 2019, 9, 4339. [CrossRef]

154. Mizutani, G.; Nakanishi, Y.; Watanabe, N.; Honma, T.; Obana, Y.; Seki, T.; Ohni, S.; Nemoto, N. Expression of Somatostatin Receptor (SSTR) Subtypes (SSTR-1, 2A, 3, 4 and 5) in Neuroendocrine Tumors Using Real-time RT-PCR Method and Immunohistochemistry. Acta Histochem. Et Cytochem. 2012, 45, 167-176. [CrossRef]

155. Qian, Z.R.; Li, T.; Ter-Minassian, M.; Yang, J.; Chan, J.A.; Brais, L.K.; Masugi, Y.; Thiaglingam, A.; Brooks, N.; Nishihara, R.; et al. Association Between Somatostatin Receptor Expression and Clinical Outcomes in Neuroendocrine Tumors. Pancreas 2016, 45, 1386-1393. [CrossRef]

156. Sampedro-Nunez, M.; Luque, R.M.; Ramos-Levi, A.M.; Gahete, M.D.; Serrano-Somavilla, A.; Villa-Osaba, A.; Adrados, M.; Ibanez-Costa, A.; Martin-Perez, E.; Culler, M.D.; et al. Presence of sst5TMD4, a truncated splice variant of the somatostatin receptor subtype 5 , is associated to features of increased aggressiveness in pancreatic neuroendocrine tumors. Oncotarget 2016, 7, 6593-6608. [CrossRef]

157. Kaemmerer, D.; Trager, T.; Hoffmeister, M.; Sipos, B.; Hommann, M.; Sanger, J.; Schulz, S.; Lupp, A. Inverse expression of somatostatin and CXCR4 chemokine receptors in gastroenteropancreatic neuroendocrine neoplasms of different malignancy. Oncotarget 2015, 6, 27566-27579. [CrossRef]

158. Barbieri, F.; Thellung, S.; Wurth, R.; Gatto, F.; Corsaro, A.; Villa, V.; Nizzari, M.; Albertelli, M.; Ferone, D.; Florio, T. Emerging Targets in Pituitary Adenomas: Role of the CXCL12/CXCR4-R7 System. Int. J. Endocrinol. 2014, 2014, 753524. [CrossRef]

159. Rostene, W.; Guyon, A.; Kular, L.; Godefroy, D.; Barbieri, F.; Bajetto, A.; Banisadr, G.; Callewaere, C.; Conductier, G.; Rovere, C.; et al. Chemokines and chemokine receptors: New actors in neuroendocrine regulations. Front. Neuroendocrinol. 2011, 32, 10-24. [CrossRef]

160. Werner, R.A.; Weich, A.; Higuchi, T.; Schmid, J.S.; Schirbel, A.; Lassmann, M.; Wild, V.; Rudelius, M.; Kudlich, T.; Herrmann, K.; et al. Imaging of Chemokine Receptor 4 Expression in Neuroendocrine Tumors -a Triple Tracer Comparative Approach. Theranostics 2017, 7, 1489-1498. [CrossRef]

161. Yao, J.; Wang, J.Y.; Liu, Y.; Wang, B.; Li, Y.X.; Zhang, R.; Wang, L.S.; Liu, L. A randomized phase II study of everolimus for advanced pancreatic neuroendocrine tumors in Chinese patients. Med. Oncol. 2014, 31, 251. [CrossRef]

162. Faivre, S.; Niccoli, P.; Castellano, D.; Valle, J.W.; Hammel, P.; Raoul, J.L.; Vinik, A.; Van Cutsem, E.; Bang, Y.J.; Lee, S.H.; et al. Sunitinib in pancreatic neuroendocrine tumors: Updated progression-free survival and final overall survival from a phase III randomized study. Ann. Oncol. Off. J. Eur. Soc. Med. Oncol. 2017, 28, 339-343. [CrossRef]

163. Vandamme, T.; Peeters, M.; Dogan, F.; Pauwels, P.; Van Assche, E.; Beyens, M.; Mortier, G.; Vandeweyer, G.; de Herder, W.; Van Camp, G.; et al. Whole-exome characterization of pancreatic neuroendocrine tumor cell lines BON-1 and QGP-1. J. Mol. Endocrinol. 2015, 54, 137-147. [CrossRef]

164. Ludvigsen, E.; Stridsberg, M.; Taylor, J.E.; Culler, M.D.; Oberg, K.; Janson, E.T. Subtype selective interactions of somatostatin and somatostatin analogs with sst1, sst2, and sst5 in BON-1 cells. Med Oncol. 2004, 21, 285-295. [CrossRef]

165. Evers, B.M.; Ishizuka, J.; Townsend, C.M.; Thompson, J.C. The human carcinoid cell line, BON. A model system for the study of carcinoid tumors. Ann. New York Acad. Sci. 1994, 733, 393-406. [CrossRef]

166. Moreno, A.; Akcakanat, A.; Munsell, M.F.; Soni, A.; Yao, J.C.; Meric-Bernstam, F. Antitumor activity of rapamycin and octreotide as single agents or in combination in neuroendocrine tumors. Endocr. -Relat. Cancer 2008, 15, 257-266. [CrossRef]

167. Herrera-Martinez, A.D.; Gahete, M.D.; Pedraza-Arevalo, S.; Sanchez-Sanchez, R.; Ortega-Salas, R.; Serrano-Blanch, R.; Luque, R.M.; Galvez-Moreno, M.A.; Castano, J.P. Clinical and functional implication of the components of somatostatin system in gastroenteropancreatic neuroendocrine tumors. Endocrine 2018, 59, 426-437. [CrossRef]

168. Herrera-Martinez, A.D.; Hofland, J.; Hofland, L.J.; Brabander, T.; Eskens, F.; Galvez Moreno, M.A.; Luque, R.M.; Castano, J.P.; de Herder, W.W.; Feelders, R.A. Targeted Systemic Treatment of Neuroendocrine Tumors: Current Options and Future Perspectives. Drugs 2019, 79, 21-42. [CrossRef] 
169. van Adrichem, R.C.; de Herder, W.W.; Kamp, K.; Brugts, M.P.; de Krijger, R.R.; Sprij-Mooij, D.M.; Lamberts, S.W.; van Koetsveld, P.M.; Janssen, J.A.; Hofland, L.J. Effects of Somatostatin Analogs and Dopamine Agonists on Insulin-Like Growth Factor 2-Induced Insulin Receptor Isoform A Activation by Gastroenteropancreatic Neuroendocrine Tumor Cells. Neuroendocrinology 2016, 103, 815-825. [CrossRef]

170. Hofving, T.; Arvidsson, Y.; Almobarak, B.; Inge, L.; Pfragner, R.; Persson, M.; Stenman, G.; Kristiansson, E.; Johanson, V.; Nilsson, O. The neuroendocrine phenotype, genomic profile and therapeutic sensitivity of GEPNET cell lines. Endocr. Relat. Cancer 2018, 25, X1-X2. [CrossRef]

171. Cambiaghi, V.; Vitali, E.; Morone, D.; Peverelli, E.; Spada, A.; Mantovani, G.; Lania, A.G. Identification of human somatostatin receptor 2 domains involved in internalization and signaling in QGP-1 pancreatic neuroendocrine tumor cell line. Endocrine 2017, 56, 146-157. [CrossRef]

172. Hofland, L.J.; Lamberts, S.W. The pathophysiological consequences of somatostatin receptor internalization and resistance. Endocr. Rev. 2003, 24, 28-47. [CrossRef]

173. Reubi, J.C.; Schonbrunn, A. Illuminating somatostatin analog action at neuroendocrine tumor receptors. Trends Pharm. Sci. 2013, 34, 676-688. [CrossRef]

174. Mohamed, A.; Romano, D.; Saveanu, A.; Roche, C.; Albertelli, M.; Barbieri, F.; Brue, T.; Niccoli, P.; Delpero, J.R.; Garcia, S.; et al. Anti-proliferative and anti-secretory effects of everolimus on human pancreatic neuroendocrine tumors primary cultures: Is there any benefit from combination with somatostatin analogs? Oncotarget 2017, 8, 41044-41063. [CrossRef]

175. Wolin, E.M. PI3K/Akt/mTOR pathway inhibitors in the therapy of pancreatic neuroendocrine tumors. Cancer Lett. 2013, 335, 1-8. [CrossRef]

176. Jiao, Y.; Shi, C.; Edil, B.H.; de Wilde, R.F.; Klimstra, D.S.; Maitra, A.; Schulick, R.D.; Tang, L.H.; Wolfgang, C.L.; Choti, M.A.; et al. DAXX/ATRX, MEN1, and mTOR pathway genes are frequently altered in pancreatic neuroendocrine tumors. Science 2011, 331, 1199-1203. [CrossRef]

177. Scarpa, A.; Chang, D.K.; Nones, K.; Corbo, V.; Patch, A.M.; Bailey, P.; Lawlor, R.T.; Johns, A.L.; Miller, D.K.; Mafficini, A.; et al. Whole-genome landscape of pancreatic neuroendocrine tumours. Nature 2017, 543, 65-71. [CrossRef]

178. Grozinsky-Glasberg, S.; Franchi, G.; Teng, M.; Leontiou, C.A.; Ribeiro de Oliveira, A., Jr.; Dalino, P.; Salahuddin, N.; Korbonits, M.; Grossman, A.B. Octreotide and the mTOR inhibitor RAD001 (everolimus) block proliferation and interact with the Akt-mTOR-p70S6K pathway in a neuro-endocrine tumour cell Line. Neuroendocrinology 2008, 87, 168-181. [CrossRef]

179. Lewis, C.S.; Elnakat Thomas, H.; Orr-Asman, M.A.; Green, L.C.; Boody, R.E.; Matiash, K.; Karve, A.; Hisada, Y.M.; Davis, H.W.; Qi, X.; et al. mTOR kinase inhibition reduces tissue factor expression and growth of pancreatic neuroendocrine tumors. J. Thromb. Haemost. JTH 2019, 17, 169-182. [CrossRef]

180. Missiaglia, E.; Dalai, I.; Barbi, S.; Beghelli, S.; Falconi, M.; della Peruta, M.; Piemonti, L.; Capurso, G.; Di Florio, A.; delle Fave, G.; et al. Pancreatic endocrine tumors: Expression profiling evidences a role for AKT-mTOR pathway. J. Clin. Oncol. 2010, 28, 245-255. [CrossRef]

181. Lee, L.; Ito, T.; Jensen, R.T. Everolimus in the treatment of neuroendocrine tumors: Efficacy, side-effects, resistance, and factors affecting its place in the treatment sequence. Expert Opin. Pharmacother. 2018, 19, 909-928. [CrossRef]

182. Perren, A.; Couvelard, A.; Scoazec, J.Y.; Costa, F.; Borbath, I.; Delle Fave, G.; Gorbounova, V.; Gross, D.; Grossma, A.; Jense, R.T.; et al. Antibes Consensus Conference, p. ENETS Consensus Guidelines for the Standards of Care in Neuroendocrine Tumors: Pathology: Diagnosis and Prognostic Stratification. Neuroendocrinology 2017, 105, 196-200. [CrossRef]

183. Pavel, M.; Valle, J.W.; Eriksson, B.; Rinke, A.; Caplin, M.; Chen, J.; Costa, F.; Falkerby, J.; Fazio, N.; Gorbounova, V.; et al. ENETS Consensus Guidelines for the Standards of Care in Neuroendocrine Neoplasms: Systemic Therapy-Biotherapy and Novel Targeted Agents. Neuroendocrinology 2017, 105, 266-280. [CrossRef]

184. Garcia-Carbonero, R.; Rinke, A.; Valle, J.W.; Fazio, N.; Caplin, M.; Gorbounova, V.; J, O.C.; Eriksson, B.; Sorbye, H.; Kulke, M.; et al. Antibes Consensus Conference, p. ENETS Consensus Guidelines for the Standards of Care in Neuroendocrine Neoplasms. Systemic Therapy 2: Chemotherapy. Neuroendocrinology 2017, 105, 281-294. [CrossRef]

185. Zandee, W.T.; Brabander, T.; Blazevic, A.; Kam, B.L.R.; Teunissen, J.J.M.; Feelders, R.A.; Hofland, J.; de Herder, W.W. Symptomatic and Radiological Response to 177Lu-DOTATATE for the Treatment of Functioning Pancreatic Neuroendocrine Tumors. J. Clin. Endocrinol. Metab. 2019, 104, 1336-1344. [CrossRef] 
186. Hicks, R.J.; Kwekkeboom, D.J.; Krenning, E.; Bodei, L.; Grozinsky-Glasberg, S.; Arnold, R.; Borbath, I.; Cwikla, J.; Toumpanakis, C.; Kaltsas, G.; et al. Antibes Consensus Conference, p., ENETS Consensus Guidelines for the Standards of Care in Neuroendocrine Neoplasia: Peptide Receptor Radionuclide Therapy with Radiolabeled Somatostatin Analogues. Neuroendocrinology 2017, 105, 295-309. [CrossRef]

187. Thang, S.P.; Lung, M.S.; Kong, G.; Hofman, M.S.; Callahan, J.; Michael, M.; Hicks, R.J. Peptide receptor radionuclide therapy (PRRT) in European Neuroendocrine Tumour Society (ENETS) grade 3 (G3) neuroendocrine neoplasia (NEN)-a single-institution retrospective analysis. Eur. J. Nucl. Med. Mol. Imaging 2018, 45, 262-277. [CrossRef]

188. Strosberg, J.R.; Halfdanarson, T.R.; Bellizzi, A.M.; Chan, J.A.; Dillon, J.S.; Heaney, A.P.; Kunz, P.L.; O'Dorisio, T.M.; Salem, R.; Segelov, E.; et al. The North American Neuroendocrine Tumor Society Consensus Guidelines for Surveillance and Medical Management of Midgut Neuroendocrine Tumors. Pancreas 2017, 46, 707-714. [CrossRef]

189. Hofland, J.; Herrera Martinez, A.D.; Zandee, W.T.; de Herder, W.W. Management of carcinoid syndrome: A systematic review and meta-analysis. Endocr. Relat. Cancer 2019. [CrossRef]

190. Khan, M.S.; El-Khouly, F.; Davies, P.; Toumpanakis, C.; Caplin, M.E. Long-term results of treatment of malignant carcinoid syndrome with prolonged release Lanreotide (Somatuline Autogel). Aliment. Pharmacol. Ther. 2011, 34, 235-242. [CrossRef]

191. Ruszniewski, P.; O'Toole, D. Ablative therapies for liver metastases of gastroenteropancreatic endocrine tumors. Neuroendocrinology 2004, 80, 74-78. [CrossRef]

192. Ruszniewski, P.; Valle, J.W.; Lombard-Bohas, C.; Cuthbertson, D.J.; Perros, P.; Holubec, L.; Delle Fave, G.; Smith, D.; Niccoli, P.; Maisonobe, P.; et al. Patient-reported outcomes with lanreotide Autogel/Depot for carcinoid syndrome: An international observational study. Dig. Liver Dis. 2016, 48, 552-558. [CrossRef]

193. Godara, A.; Siddiqui, N.S.; Byrne, M.M.; Saif, M.W. The safety of lanreotide for neuroendocrine tumor. Expert Opin. Drug Saf. 2019, 18, 1-10. [CrossRef]

194. Modlin, I.M.; Pavel, M.; Kidd, M.; Gustafsson, B.I. Review article: Somatostatin analogues in the treatment of gastroenteropancreatic neuroendocrine (carcinoid) tumours. Aliment. Pharm. Ther. 2010, 31, 169-188.

195. Li, S.C.; Martijn, C.; Cui, T.; Essaghir, A.; Luque, R.M.; Demoulin, J.B.; Castano, J.P.; Oberg, K.; Giandomenico, V. The somatostatin analogue octreotide inhibits growth of small intestine neuroendocrine tumour cells. PLoS ONE 2012, 7, e48411. [CrossRef]

196. Chan, D.L.; Segelov, E.; Singh, S. Everolimus in the management of metastatic neuroendocrine tumours. Ther. Adv. Gastroenterol. 2017, 10,132-141. [CrossRef]

197. Kvols, L.K.; Oberg, K.E.; O’Dorisio, T.M.; Mohideen, P.; de Herder, W.W.; Arnold, R.; Hu, K.; Zhang, Y.; Hughes, G.; Anthony, L.; et al. Pasireotide (SOM230) shows efficacy and tolerability in the treatment of patients with advanced neuroendocrine tumors refractory or resistant to octreotide LAR: Results from a phase II study. Endocr. Relat. Cancer 2012, 19, 657-666. [CrossRef]

198. Wolin, E.M.; Jarzab, B.; Eriksson, B.; Walter, T.; Toumpanakis, C.; Morse, M.A.; Tomassetti, P.; Weber, M.M.; Fogelman, D.R.; Ramage, J.; et al. Phase III study of pasireotide long-acting release in patients with metastatic neuroendocrine tumors and carcinoid symptoms refractory to available somatostatin analogues. Drug Des. Dev. Ther. 2015, 9, 5075-5086. [CrossRef]

199. Kulke, M.H.; Ruszniewski, P.; Van Cutsem, E.; Lombard-Bohas, C.; Valle, J.W.; De Herder, W.W.; Pavel, M.; Degtyarev, E.; Brase, J.C.; Bubuteishvili-Pacaud, L.; et al. A randomized, open-label, phase 2 study of everolimus in combination with pasireotide LAR or everolimus alone in advanced, well-differentiated, progressive pancreatic neuroendocrine tumors: COOPERATE-2 trial. Ann. Oncol. 2017, 28, 1309-1315. [CrossRef]

200. Yao, J.C.; Chan, J.A.; Mita, A.C.; Kundu, M.G.; Hermosillo Resendiz, K.; Hu, K.; Ravichandran, S.; Strosberg, J.R.; Wolin, E.M. Phase I dose-escalation study of long-acting pasireotide in patients with neuroendocrine tumors. OncoTargets Ther. 2017, 10, 3177-3186. [CrossRef]

201. Cives, M.; Kunz, P.L.; Morse, B.; Coppola, D.; Schell, M.J.; Campos, T.; Nguyen, P.T.; Nandoskar, P.; Khandelwal, V.; Strosberg, J.R. Phase II clinical trial of pasireotide long-acting repeatable in patients with metastatic neuroendocrine tumors. Endocr. Relat. Cancer 2015, 22, 1-9. [CrossRef] 
202. Ferolla, P.; Brizzi, M.P.; Meyer, T.; Mansoor, W.; Mazieres, J.; Do Cao, C.; Lena, H.; Berruti, A.; Damiano, V.; Buikhuisen, W; et al. Efficacy and safety of long-acting pasireotide or everolimus alone or in combination in patients with advanced carcinoids of the lung and thymus (LUNA): An open-label, multicentre, randomised, phase 2 trial. Lancet. Oncol. 2017, 18, 1652-1664. [CrossRef]

203. Kaderli, R.M.; Spanjol, M.; Kollar, A.; Butikofer, L.; Gloy, V.; Dumont, R.A.; Seiler, C.A.; Christ, E.R.; Radojewski, P.; Briel, M.; et al. Therapeutic Options for Neuroendocrine Tumors: A Systematic Review and Network Meta-analysis. JAMA Oncol. 2019. [CrossRef]

204. Gaudenzi, G.; Albertelli, M.; Dicitore, A.; Wurth, R.; Gatto, F.; Barbieri, F.; Cotelli, F.; Florio, T.; Ferone, D.; Persani, L.; et al. Patient-derived xenograft in zebrafish embryos: A new platform for translational research in neuroendocrine tumors. Endocrine 2017, 57, 214-219. [CrossRef]

205. Wurth, R.; Barbieri, F.; Pattarozzi, A.; Gaudenzi, G.; Gatto, F.; Fiaschi, P.; Ravetti, J.L.; Zona, G.; Daga, A.; Persani, L.; et al. Phenotypical and Pharmacological Characterization of Stem-Like Cells in Human Pituitary Adenomas. Mol. Neurobiol. 2017, 54, 4879-4895. [CrossRef]

(C) 2019 by the authors. Licensee MDPI, Basel, Switzerland. This article is an open access article distributed under the terms and conditions of the Creative Commons Attribution (CC BY) license (http://creativecommons.org/licenses/by/4.0/). 